\title{
Redefining diabetes mellitus treatments according to different mechanisms beyond hypoglycaemic effect
}

\author{
Savina Nodari ${ }^{1}$ (I) $\cdot$ Francesco Fioretti $^{1} \cdot$ Francesco Barilla $^{2}$ \\ Accepted: 9 December 2021 \\ ( ) The Author(s), under exclusive licence to Springer Science+Business Media, LLC, part of Springer Nature 2022
}

\begin{abstract}
Early epidemiologic studies in type 2 diabetes suggested that the long-term risk of microvascular and macrovascular complications increase progressively as glucose concentrations rise, inspiring the pursuit of near euglycaemia as a means of preventing these complications in type 1 and type 2 diabetes. Evidence emerging over the past decade, however, showed that the aggressive efforts often needed to achieve low HbA1c levels can ultimately lead to worse clinical outcomes, greater risk of severe hypoglycaemia, and higher burden of treatment. The acknowledgment of the disappointing results obtained with therapies aimed exclusively at improving glycaemic control has led in recent years to a substantial paradigm shift in the treatment of the diabetic patient. The results obtained first with GLP-1RAs and more recently even more with SGLT2i on mortality and CV events have made it clear how other mechanisms, beyond the hypoglycaemic effect, are at the basis of the benefits observed in several cardiovascular outcome trials. And as evidence of the great revolution of thought we are experiencing, there is the recognition of gliflozins as drugs for the treatment not only of diabetic patients but also of nondiabetic patients suffering from HF, as reported in the latest ESC/HFA guidelines. Surely, we still have a lot to understand, but it is certain that this is the beginning of a new era.
\end{abstract}

Keywords Diabetes mellitus · Cardiovascular risk · SGLT2i · GLP-1RAs · Metabolic syndrome $\cdot$ Hyperglicemia

\section{Introduction}

The vast majority of people with hyperglycaemia have type 2 diabetes (T2DM), characterized by progressive insulin resistance and subsequent hyperglycaemia [1]. Early epidemiologic studies in T2DM suggested that the long-term risk of microvascular and macrovascular complications increases progressively as glucose concentrations rise, inspiring the pursuit of near euglycaemia as a means of preventing these complications in type 1 and T2DM [2-4].

This glucocentric approach was bolstered by early large randomized controlled trials (RCTs) of intensive glucose lowering therapy [the Diabetes Control and Complications Trial (DCCT) [5] among patients with type 1 diabetes and the United Kingdom Prospective Diabetes Study (UKPDS)

Savina Nodari

savina.nodari@unibs.it

1 Department of Medical and Surgical Specialities, Radiological Sciences and Public Health, University and Spedali Civili of Brescia, Brescia, Italy

2 Department of System's Medicine, Tor Vergata University, Rome, Italy
[6] among patients with newly or recently diagnosed T2DM] which showed reductions in the early manifestations of microvascular complications with intensive glycaemic control. Importantly, these trials defined intensive control by plasma glucose rather than glycosylated haemoglobin A1c (HbA1c) targets: fasting glucose $70-120 \mathrm{mg} / \mathrm{dL}(3.9-6.7 \mathrm{mmol} / \mathrm{L})$ and postprandial glucose below $180 \mathrm{mg} / \mathrm{dL}(10 \mathrm{mmol} / \mathrm{L})$ in the DCCT intensive treatment arm [5], and fasting glucose below $106 \mathrm{mg} / \mathrm{dL}(<6 \mathrm{mmol} / \mathrm{L})$ versus glucose below $270 \mathrm{mg} / \mathrm{dL}$ $(<15 \mathrm{mmol} / \mathrm{L})$ in the UKPDS intensive and standard treatment arms, respectively [6]. However, most clinical guidelines then used these results to recommend intensive control as defined by $\mathrm{HbA} 1 \mathrm{c}$ below $6.5-7.0 \%$ (48-53 $\mathrm{mmol} / \mathrm{mol}$ ) [7-9], extrapolating from improved outcomes achieved by patients who had mean $\mathrm{HbA} 1 \mathrm{c} 7.0 \%$ (53 mmol/mol) compared with $9.0 \%$ $(75 \mathrm{mmol} / \mathrm{mol})$ in DCCT or $7.9 \%$ (63 mmol/mol) in UKPDS.

Evidence emerging over the past decade, however, showed that the aggressive efforts often needed to achieve low HbA1c levels can ultimately lead to worse clinical outcomes, greater risk of severe hypoglycaemia, and higher burden of treatment [10-13]. In fact, it was observed that intensive glycaemic control does not seem to reduce allcause mortality in patients with T2DM [13]. 
Therefore, although glycaemic control is associated with reduction in the risk of microvascular complications, the macrovascular benefits of intensive glycaemic control are less supported. Furthermore, concern has been raised about the cardiovascular (CV) safety of glucose-lowering drugs [14]. Consequently, regulatory authorities have mandated CV safety assessments of new diabetes treatments [15-17].

For this purpose, CV outcome trials (CVOTs) were designed to examine the CV safety of glucose-lowering drugs. They showed that microvascular (for example, kidney) [18-25] and macrovascular (for example, atherosclerotic cardiovascular disease, heart failure [HF]) [19-21, 26-29] health outcomes can be meaningfully improved without extreme reduction of $\mathrm{HbAlc}$.

Therefore, the paradigm of diabetes management is shifting from a "glucose-centred" to a "metabolic-centred" approach because of the strong evidences that this novel approach can reduce overall risk of cardio-nephro-vascular complications [30]. So, it is important to understand how T2DM treatment changed during the last years.

In this paper, we will cover the main changes in the therapeutic approach of T2DM throughout the last years.

\section{The past}

Early observational studies suggested an association between the extent of hyperglycaemia and the risk of death and of macrovascular and microvascular disease in patients with T2DM [2-4].

For example, the UK Prospective Diabetes Study (UKPDS) evaluated the relationship between the exposure to hyperglycaemia over time and the risk of macrovascular or microvascular complications in patients with T2DM [2] collecting data in 23 hospital based clinics in England, Scotland and Northern Ireland. For this purpose, 4585 white, Asian Indian and Afro-Caribbean patients, randomized or not to treatment, were included in analyses of incidence; of these, 3642 were included in analyses of relative risk. Primary predefined aggregate clinical outcomes were any end point or deaths related to diabetes and cause mortality, whereas secondary aggregate outcomes were myocardial infarction, stroke, amputation (including death from peripheral vascular disease) and microvascular disease (predominantly retinal photo-coagulation). After 10 years of followup, data showed that the incidence of clinical complications was significantly associated with glycaemic levels. Each $1 \%$ reduction in updated mean $\mathrm{HbA1c}$ was associated with reductions in risk of $21 \%$ for any end point related to diabetes (95\% confidence interval 17 to $24 \%, P<0.0001$ ), $21 \%$ for deaths related to diabetes ( 15 to $27 \%, P<0.0001$ ), $14 \%$ for myocardial infarction ( 8 to $21 \%, P<0.0001)$ and $37 \%$ for microvascular complications (33 to $41 \%, P<0.0001$ ).
No threshold of risk was observed for any end point. Therefore, the researchers concluded that in patients with T2DM, the risk of diabetic complications is strongly associated with previous hyperglycaemia. Any reduction in $\mathrm{HbA1c}$ is likely to reduce the risk of complications, with the lowest risk being in those with $\mathrm{HbAlc}$ values in the normal range $(<6.0 \%)$ [2].

The graded relationship between the HbA1c levels and $\mathrm{CV}$ events and death suggested that a therapeutic strategy of lowering $\mathrm{HbA} 1 \mathrm{C}$ levels might reduce these outcomes. For this reason, studies investigating whether intensive therapy to reach the HbA1c and glycaemic target levels could reduce the risk of complications were performed.

The Action to Control Cardiovascular Risk in Diabetes (ACCORD) trial was a randomized, multicenter, double $2 \times 2$ factorial design study specifically designed to determine whether a therapeutic strategy targeting normal $\mathrm{HbA} 1 \mathrm{c}$ levels (i.e., below 6.0\%) could reduce the rate of $\mathrm{CV}$ events, as compared with a strategy targeting $\mathrm{HbA} 1 \mathrm{c}$ levels from 7.0 to $7.9 \%$, in 10,251 middle-aged and older participants with T2DM and either established CV disease or additional CV risk factors [31]. Participants should have been treated and followed for 4-8 years (approximate mean, 5.6 years). The primary outcome was the first occurrence of a major cardiovascular event, specifically a composite outcome of non-fatal myocardial infarction (MI), non-fatal stroke, or CV death. Secondary outcomes included other CV outcomes, total mortality, diabetic microvascular disease (retinopathy, nephropathy, and neuropathy), health-related quality of life, and cost-effectiveness. The finding of higher mortality in the intensive-therapy group led to a decision to terminate the intensive regimen in February 2008, 17 months before the scheduled end of the study [31].

In 2011, to assess the effect of targeting "intensive" glycaemic control versus "conventional" glycaemic control, on all-cause mortality and CV mortality, non-fatal MI, microvascular complications, and severe hypoglycaemia, in T2DM patients, a systematic review with meta-analyses and trial sequential analyses of randomized trials were performed [13].

Fourteen clinical trials that randomized 28,614 participants with T2DM $(15,269$ scheduled to intensive control and 13,345 to conventional control) were included. It was observed that intensive glycaemic control did not significantly affect the relative risks of all-cause mortality (1.02, $95 \%$ confidence interval 0.91 to $1.13 ; P=\mathrm{NS} ; 28,359$ participants, 12 trials) or CV mortality (1.11, 0.92 to 1.35 ; $P=\mathrm{NS} ; 28,359$ participants, 12 trials). Trial sequential analyses rejected a relative risk reduction above $10 \%$ for all-cause mortality and showed insufficient data on CV mortality. The risk of non-fatal MI may be reduced (relative risk $0.85,0.76$ to $0.95 ; P=0.004 ; 28,111$ participants, 8 trials), but this finding was not confirmed in trial sequential 
analysis. Intensive glycaemic control showed a reduction of the relative risk for the composite microvascular outcome ( $0.88,0.79$ to $0.97 ; P=0.01 ; 25,600$ participants, 3 trials) and retinopathy $(0.80,0.67$ to $0.94 ; P=0.009 ; 10,793$ participants, 7 trials), but trial sequential analyses showed that sufficient evidence had not yet been reached. The estimate of an effect on the risk of nephropathy (relative risk 0.83 , 0.64 to $1.06 ; 27769$ participants, 8 trials) was not statistically significant. The risk of severe hypoglycaemia was significantly increased when intensive glycaemic control was targeted (relative risk $2.39,1.71$ to $3.34 ; P<0.001 ; 27,844$ participants, 9 trials); trial sequential analysis supported a $30 \%$ increased relative risk of severe hypoglycaemia (Fig. 1).

Based on these results, researchers concluded that intensive glycaemic control did reduce all-cause mortality in patients with T2DM and the data available were insufficient to prove or refute a relative risk reduction for $\mathrm{CV}$ mortality, non-fatal MI, composite microvascular complications, or retinopathy at a magnitude of $10 \%$. On the other hand, intensive glycaemic control increased the relative risk of severe hypoglycaemia by $30 \%$.

Another systematic review was performed to summarize the benefits of intensive vs conventional glucose control on kidney-related outcomes in adults with T2DM [32]. Three databases were systematically searched (from January 1, 1950 , to December 31, 2010) to identify randomized trials that compared surrogate renal end points (microalbuminuria and macroalbuminuria) and clinical renal end points (doubling of the serum creatinine level, end-stage renal disease [ESRD] and death from renal disease) in T2DM patients receiving the two different treatment strategies.

Compared with conventional control, intensive glucose control reduced the risk for microalbuminuria (risk ratio, 0.86 [95\% CI, 0.76-0.96]) and macroalbuminuria (risk ratio, 0.74 [95\% CI, 0.65-0.85]), but not doubling of the serum creatinine level (1.06 [0.92-1.22]), ESRD (0.69
[0.46-1.05]), or death from renal disease (0.99 [0.55-1.79]) (Fig. 2).

These data allowed researchers to say that intensive glucose control reduces the risk for microalbuminuria and macroalbuminuria, but evidence is lacking that intensive glycaemic control reduces the risk for significant clinical renal outcomes, such as doubling of the serum creatinine level, ESRD, or death from renal disease, during the years of follow-up of the trials considered [32].

Despite the unfavourable results of an intensive glycaemic control on $\mathrm{CV}$ outcomes in diabetic patients observed in several studies, it is important to note that $\mathrm{HbA} 1 \mathrm{c}$ has been found to be one of the strongest predictors for death for any cause, or hospitalization for HF but especially for atherothrombotic events (acute myocardial infarction, stroke). This surely underlines the importance of dysglycaemia in developing CV complication [33].

Despite the role of $\mathrm{HbAlc}$ as one of the strongest predictors of cardiovascular events, it is also important to know the role on cardiovascular outcomes of other risk factors frequently concomitant in diabetic patients.

For this purpose, several observational studies and clinical trials on intensified multifactorial intervention in diabetic patients were performed in the last years. However, they showed inconsistent results about the benefit on cardiovascular outcomes (CV death, acute myocardial infarction, nonfatal stroke, hospitalization for heart failure) and on all-cause mortality.

Recently, the analysis of a wide Swedish nationwide registry data [33] from 1998 through 2012 showed that low physical activity, smoking, and glycated haemoglobin, systolic blood-pressure, and LDL cholesterol levels outside the target ranges were considered to be the strongest predictors for cardiovascular outcomes and death. Moreover, in patients with type 2 diabetes and multiple risk factors, the reaching target range for each variable was associated with,

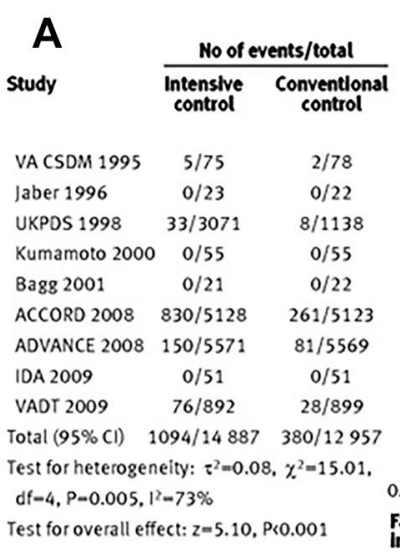

Fig. 1 Forest plots for all-cause mortality (a) and for severe hypoglycaemia (b) [13]

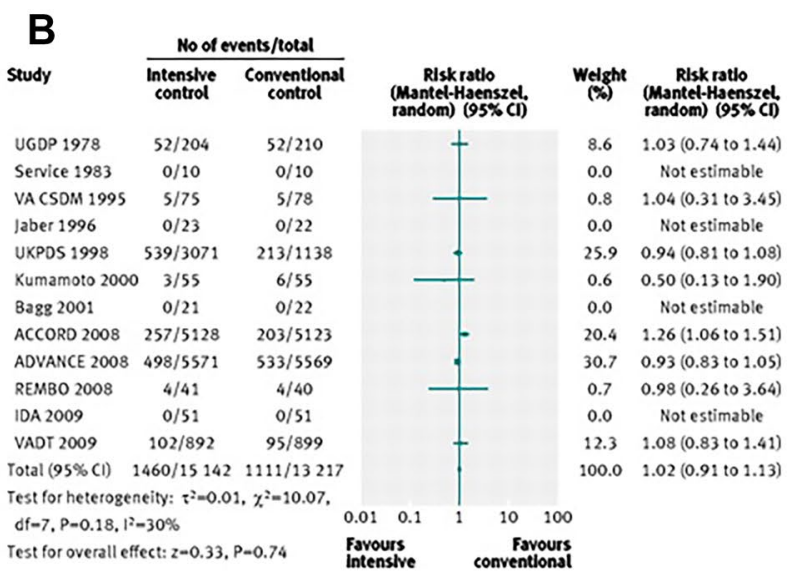


A Doubling of the Serum Creatinine Level

\begin{tabular}{|c|c|c|}
\hline \multirow[b]{2}{*}{ Study or Subgroup } & \multicolumn{2}{|c|}{ Intensive Therapy } \\
\hline & Events & Total \\
\hline$A C C O R 0^{8.14}$ & 392 & 5041 \\
\hline ADVANCE $^{12}$ & 67 & 5571 \\
\hline UKPOS $33^{16}$ & 7 & 2150 \\
\hline VADT"11 & 78 & 882 \\
\hline Total (95\% Cl) & & 13644 \\
\hline Total events & 544 & \\
\hline
\end{tabular}

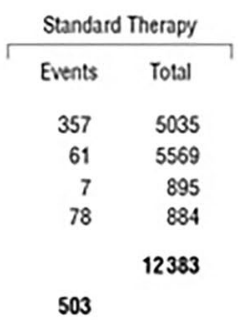

503

B ESRD

\begin{tabular}{|c|c|c|}
\hline \multirow[b]{2}{*}{ Study or Subgroup } & \multicolumn{2}{|c|}{ Intensive Therapy } \\
\hline & Events & Total \\
\hline ACCORD 8.14 & 138 & 5119 \\
\hline ADVANCE ${ }^{12}$ & 11 & 5571 \\
\hline UKPOS $33^{16}$ & 16 & 2729 \\
\hline UKPOS $34^{17}$ & 2 & 342 \\
\hline VADT 11 & 7 & 882 \\
\hline Total $(95 \% \mathrm{Cl})$ & & 14643 \\
\hline Total events & 174 & \\
\hline
\end{tabular}

\begin{tabular}{|rr|}
\hline \multicolumn{2}{|c|}{ Standard Therapy } \\
\hline Events & Total \\
151 & 5115 \\
31 & 5569 \\
9 & 1138 \\
2 & 411 \\
11 & 884 \\
& 13117 \\
204 & \\
\hline
\end{tabular}
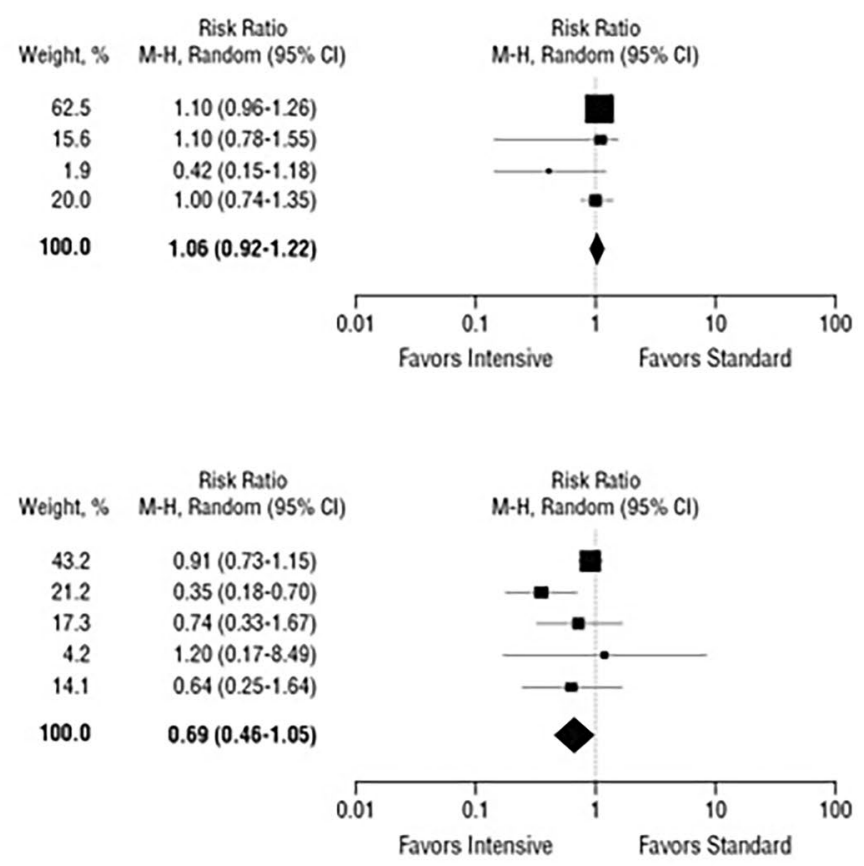

C Death From Renal Disease

\begin{tabular}{lcr|} 
& \multicolumn{2}{c}{ Intensive Therapy } \\
\cline { 2 - 3 } Study or Subgroup & Events & Total \\
ADVANCE & & \\
UKPOS $33^{16}$ & 16 & 5571 \\
UKPOS $34^{17}$ & 8 & 2728 \\
Total $(95 \% \mathrm{Cl})$ & 2 & 342 \\
Total events & & 8641 \\
Heterogeneity: $\tau^{2}=0.00 ; x_{2}^{3}=1.19 ; P=.55 ;$ & $R=0 \%$ \\
Test for overall effect: $z=0.03 ; P=.98$
\end{tabular}

\begin{tabular}{|rr|}
\multicolumn{2}{|c|}{ Standard Therapy } \\
\hline Events & Total \\
19 & 5569 \\
2 & 1138 \\
1 & 411 \\
& 7118 \\
22 & \\
\hline
\end{tabular}

Fig. 2 Pooled risk ratios (RRs), with 95\% CI, by trial for clinical renal end points (doubling of the serum creatinine level and end-stage renal disease [ESRD]) [32]

at most, marginally higher risks of death, stroke, and myocardial infarction than the general population. So theoretically, having all risk-factor variables within the target ranges could eliminate the excess risk of cardiovascular events. Furthermore, a strong relationship between younger age and increasing number of risk factors above target ranges, and an increased relative risk of cardiovascular events, was identified, suggesting that there may be greater potential benefit from more aggressive treatment in younger diabetic patients.

In addition, atrial fibrillation, high body mass index, glycated haemoglobin levels, and renal function outside the target ranges resulted to be the strongest predictors of hospitalization for heart failure, indicating that cardio-renal mechanisms may play a role in the development of heart failure in these patients [33].

However, the effect of glycaemic control on HF outcomes is controversial. Observational studies examining glycaemic control in diabetic patients suggest a positive effect on the primary prevention of heart failure. In fact, in the UKPDS study [2], a log-linear relation between heart failure risk and long-term glycaemic control was evident, with a $1 \%$ reduction in $\mathrm{HbA} 1 \mathrm{c}$ associated with a $16 \%$ risk reduction in the development of HF. Despite this evidence, randomized controlled trials ACCORD, ADVANCE, and VADT, examining the effect of intensive glycaemic control on CV outcomes when combined with the primary prevention, showed that intensive glycaemic control did not reduce the risk of hospitalization for HF [34]. Moreover, several retrospective studies suggest worse prognosis in patients with diabetes mellitus and $\mathrm{HF}$ with an $\mathrm{HbA1c}$ less than 7\%. The relationship between glycaemic control and HF outcomes is made more difficult by the role of anti-hyperglycaemic therapy. Analysis of the UK General Practice Research Database concluded that the use of any anti-hyperglycaemic drug (as compared 
Fig. 3 Type 2 diabetes may be considered as a cardio-renalmetabolic disease that develops through the interaction of a variable mix of genetic and environmental factors that disturb metabolic homeostasis and give rise to cardiovascular (CV), renal and other complications [36]

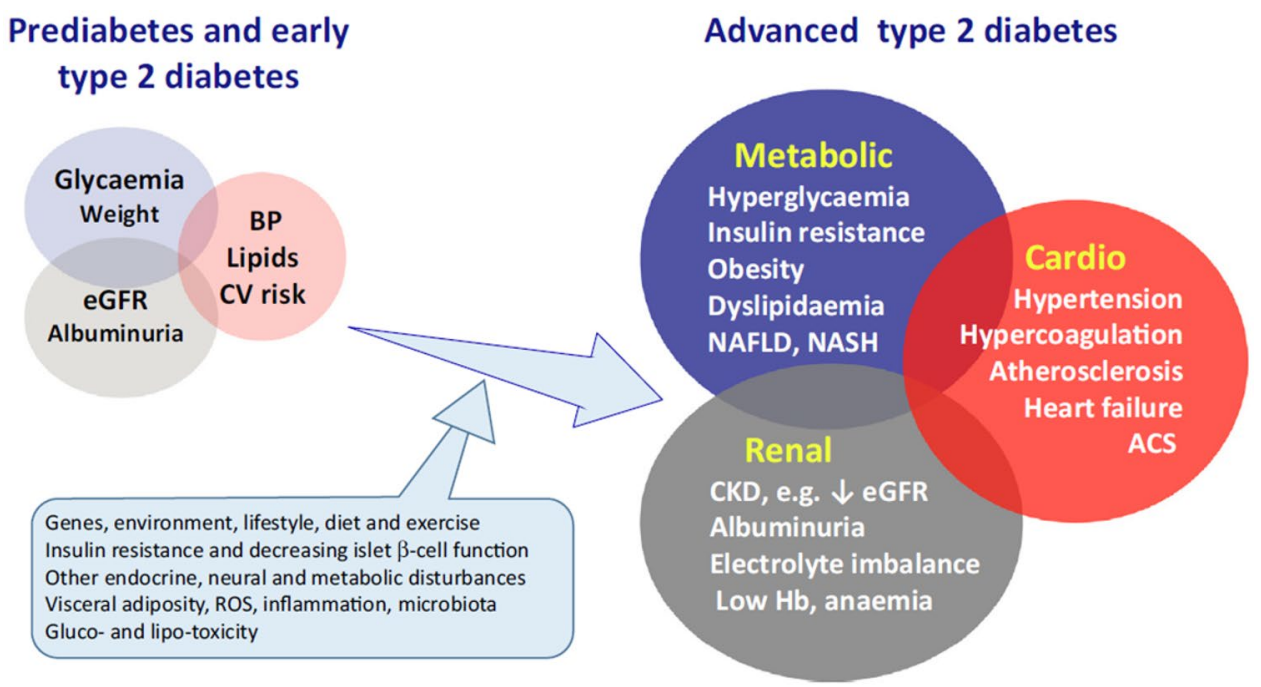

with no drug treatment) was associated with increased risk of HF, though mostly in the short term. Although probably drug intervention is more likely to be used in patients at higher risk of HF, it is also possible that lowering of plasma glucose might precipitate HF in those at highest risk. From a mechanistic viewpoint, it seems plausible that a reduction in plasma glucose, in some way, might adversely affect cardiac function. Alternatively and additionally, hypoglycaemic episodes might induce sympathetic nervous system activation and increase heart rate, which, if frequent and prolonged, could be prothrombotic and arrhythmogenic as well as detrimental to the left ventricular remodelling process in susceptible individuals [35].

In conclusion, the body of evidence shows no meaningful benefit of intensive (compared with moderate) glycaemic control for microvascular and macrovascular outcomes. Intensive glycaemic control does, however, increase the risk of severe hypoglycaemia and incurs additional burden by way of polypharmacy, side effects, and cost [1].

\section{The present}

The different metabolic disturbances of T2DM and the associated microvascular and macrovascular complications are on the whole considered as a single cardio-renal-metabolic disease entity (Fig. 3) [36]. The metabolic disturbances, such as hyperglycaemia and dyslipidaemia, are consequent to overnutrition, insulin resistance, defects of insulin secretion, and other endocrine abnormalities. Taken together, these and other $\mathrm{CV}$ risk factors such as inflammation and a pro-coagulant state contribute to the increased occurrence of atherothrombotic diseases which account for up to half of total mortality among T2DM patients [36].
So far, treatment of T2DM was essentially concerned with optimizing glycaemic control, facilitating weight control, and managing $\mathrm{CV}$ risk. Over the last two decades, several new classes of glucose-lowering agents have become available. These include incretins such as glucagon-like peptide-1 receptor agonists (GLP-1RAs), dipeptidyl peptidase 4 (DPP4) inhibitors, and sodium-glucose cotransporter-2 inhibitors (SGLT2i). These agents may be used as monotherapy or in combination with more established agents and insulin [37]. To address concerns over the CV safety of new anti-diabetic agents, the US Food and Drug Administration (FDA) imposed to conduct large prospective CV outcome trials (CVOTs), as "conditio sine qua non" for obtaining the approval [13, 15, 17]. These trials showed the CV safety of the new anti-diabetic drugs [38-42] (confirmed by post-marketing data), raising expectations about their possible protective effects against $\mathrm{CV}$ and renal complications beyond the benefits conferred by glycaemic control alone [43]. In fact, prevention of nonfatal and fatal CV events is a key goal of the management of patients with T2DM.

Notably, in addition to blood pressure-lowering and cholesterol-lowering therapies, in particular two of the newer classes of anti-hyperglycaemic drugs, SGLT2i and GLP1RAs, have been shown to reduce CV risk [38].

\section{DPP-4 inhibitors}

Since their introduction in 2006, DPP-4 inhibitors, which enhance the endogenous incretin effect, have become widely used, especially as add-on to metformin. Although glucoselowering potency may be limited, particularly for individuals with hyperglycaemia consequent to inadequate residual betacell function, these agents incur little risk of hypoglycaemia or weight gain [36]. 
Several meta-analyses of RCTs with each of the DPP-4 inhibitors commercialized in the United States and in Europe, alogliptin [44], saxagliptin [45], sitagliptin [46], linagliptin [47], and vildagliptin [41], generally reported a non-significant reduction of MACE compared with placebo or other active anti-diabetic compounds. Because of the low number of MACE in each DPP-4 inhibitor-specific meta-analysis, the differences failed to reach statistical significance, thus paving the road to pooled analysis. Overall, data from meta-analyses did not show evidence of harm and showed neutral to beneficial effects for a variety of CV outcomes depending on the analysis (Table 1) [48].

Neutral CV effects were reported when pooling the results of all phase 2 to phase 3 trials and of the main three CV outcome trials: EXAMINE [Examination of
Cardiovascular Outcomes: Alogliptin vs Standard of Care in Patients with Type 2 Diabetes Mellitus and Acute Coronary Syndrome], SAVOR-TIMI 53 [Saxagliptin Assessment of Vascular Outcomes Recorded in Patients With Diabetes Mellitus-Thrombolysis in Myocardial Infarction 53], and TECOS [Trial Evaluating Cardiovascular Outcomes with Sitagliptin] [40, 42]. No significant differences were observed in meta-analyses that compared DPP-4 inhibitors with combined placebo or active glucoselowering medications and in meta-analyses that compared DPP-4 inhibitors with placebo only [41]. Three metaanalyses of the prospective CV outcome trials (EXAMINE, SAVOR-TIMI 53, TECOS) failed to demonstrate any positive effect of DPP-4 inhibitors compared with placebo on CV outcomes and mortality (Table 2) [49-51].

Table 1 Cardiovascular events and mortality rates with DPP-4 inhibitors in meta-analyses of phase 2 to 3 randomized controlled trials (excluding the 3 cardiovascular outcome Trials) [48]

\begin{tabular}{|c|c|c|c|c|c|c|c|}
\hline DPP-4 inhibitor & Alogliptin & Saxagliptin & Sitagliptin & Linagliptin & Vildagliptin & $\begin{array}{l}\text { All DPP-4 } \\
\text { inhibitors } \\
\text { Monami et al }\end{array}$ & $\begin{array}{l}\text { All DPP-4 } \\
\text { inhibitors } \mathrm{Xu} \\
\text { et al }\end{array}$ \\
\hline No. of trials & 11 & 20 & 25 & 8 & 40 & $70 *$ & $35^{\mathrm{a}}$ \\
\hline Daily dose, $\mathrm{mg}$ & $12.5-25$ & $2.5-10$ & 100 & $5-10$ & 1 or $2 \times 50$ & variable & variable \\
\hline $\begin{array}{l}\text { Patients (n) } \\
\text { DPP-4 inhibi- } \\
\text { tors vs all com- } \\
\text { parators }\end{array}$ & 4162 vs 1855 & 5701 vs 3455 & 7726 vs 6885 & 3319 vs 1920 & 9599 vs 7847 & 41959 (total) & 29600 (total) \\
\hline $\begin{array}{l}\text { Primary compos- } \\
\text { ite cardiovascu- } \\
\text { lar end point }{ }^{\mathrm{b}}\end{array}$ & $\begin{array}{l}0.635 \\
\quad(0-1.406)\end{array}$ & $\begin{array}{l}0.75(0.46- \\
1.21)\end{array}$ & $\begin{array}{l}0.83(0.53- \\
1.30)^{\mathrm{c}}\end{array}$ & $\begin{array}{l}0.34(0.16- \\
0.70)\end{array}$ & $\begin{array}{l}0.84(0.62- \\
1.14)\end{array}$ & $\begin{array}{l}0.71(0.59- \\
0.86) \\
P<0.001\end{array}$ & $0.91(0.53-1.56)$ \\
\hline $\begin{array}{r}\text { Myocardial } \\
\text { infarction }\end{array}$ & NA & IRR, 0.87 & NA & $\begin{array}{l}0.52(0.17- \\
1.54)\end{array}$ & $\begin{array}{l}0.87(0.56- \\
1.38)\end{array}$ & $\begin{array}{l}0.64(0.44- \\
0.94) \\
P=0.023\end{array}$ & $0.71(0.49-1.03)$ \\
\hline Stroke & NA & IRR, 0.75 & NA & $\begin{array}{l}0.11(0.02- \\
0.51)\end{array}$ & $\begin{array}{l}0.84(0.47- \\
1.50)\end{array}$ & $\begin{array}{l}0.77(0.48- \\
1.24) \\
P=0.290\end{array}$ & $0.61(0.37-0.98)$ \\
\hline $\begin{array}{l}\text { Hospitalization } \\
\text { for heart failure }\end{array}$ & NA & IRR, 0.55 & NA & NA & $\begin{array}{l}1.08(0.68- \\
1.70)\end{array}$ & NA & $1.01(0.53-1.94)$ \\
\hline $\begin{array}{l}\text { Cardiovascular } \\
\text { mortality }\end{array}$ & NA & IRR, 0.61 & NA & $\begin{array}{l}0.74(0.10- \\
5.33)\end{array}$ & $\begin{array}{l}0.77(0.45- \\
1.31)\end{array}$ & $\begin{array}{l}0.67(0.39- \\
1.14) \\
P=0.140\end{array}$ & $0.91(0.53-1.56)$ \\
\hline $\begin{array}{l}\text { All-cause mortal- } \\
\text { ity }\end{array}$ & NA & NA & NA & $\begin{array}{l}1.02(0.23- \\
4.63)\end{array}$ & $\begin{array}{l}0.91(0.77- \\
1.08)^{\mathrm{d}}\end{array}$ & $\begin{array}{l}0.60(0.41- \\
0.88) \\
P=0.008\end{array}$ & $0.77(0.56-1.07)$ \\
\hline
\end{tabular}

Comparators are placebo or active glucose-lowering agents. Results are expressed as hazard ratio or odds ratio (95\% confidence intervals) and $P$ value when available

$D P P-4$ dipeptidyl peptidase-4, $H R$ hazard ratio, IRR incidence rate ratio, $N A$ not available

*Placebo (45 trials)/active (18 trials)/both comparators ( 7 trials)

${ }^{a}$ Eleven trials vs placebo and 24 trials vs active comparators: no difference between the 2 sets of trials except for stroke: 0.74 (0.25-2.20) vs placebo and 0.58 (0.34-0.99) vs active comparators

${ }^{\mathrm{b}}$ Cardiovascular mortality, nonfatal myocardial infarction, and nonfatal stroke

${ }^{\mathrm{c}}$ Sitagliptin $(n=5236)$ vs placebo $(n=4548)$ only: HR $=1.01(0.53-1.86)$

${ }^{\mathrm{d}}$ All-cause mortality combined with any cardiovascular event 


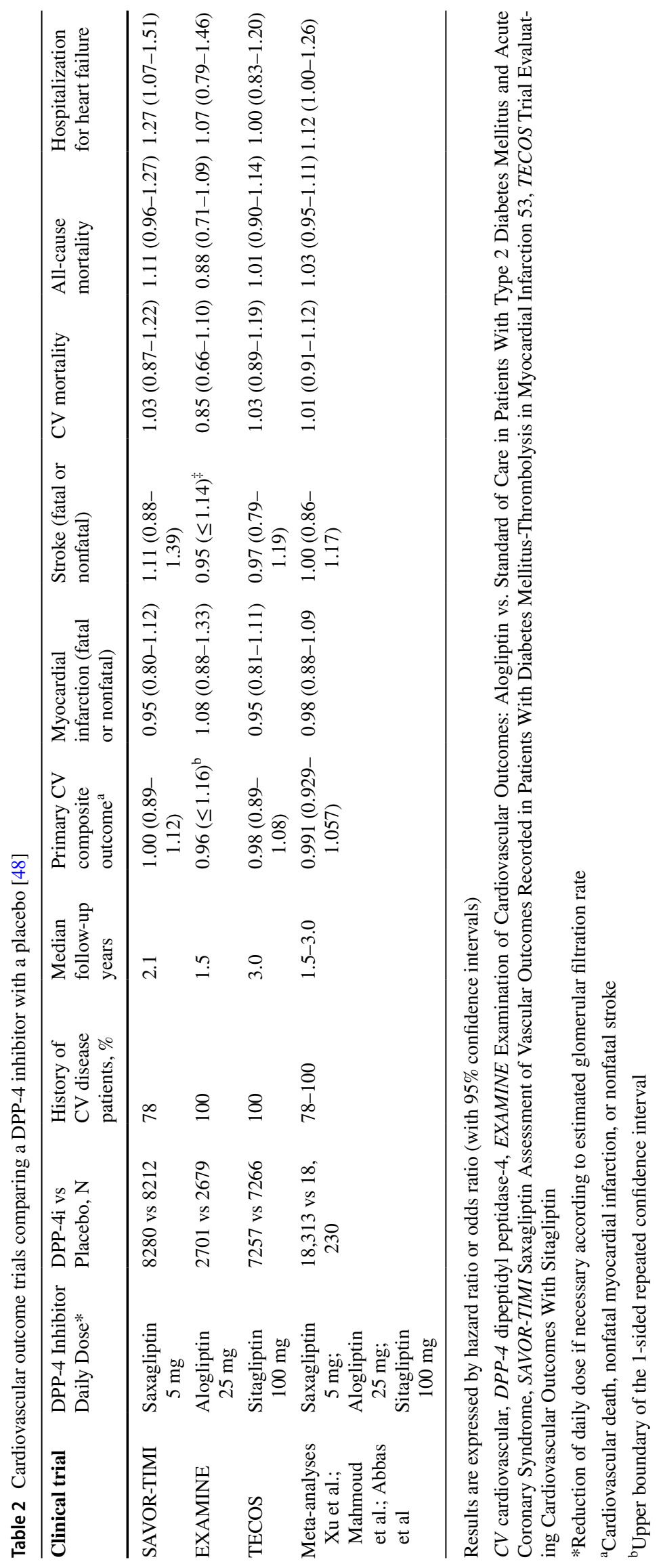


In the SAVOR-TIMI 53 trial, more patients in the saxagliptin group than in the placebo group were hospitalized for HF (3.5\% versus $2.8 \% ; p=0.007)$ [52]. This increased risk of HF was highest among T2DM patients with elevated levels of natriuretic peptides, prior HF, or chronic kidney disease (CKD) at entry of the study. The risk of HF hospitalization was increased irrespective of age category while high baseline $\mathrm{HbA1c}$ was not shown to be a risk factor. Of note, this higher rate of HF hospitalization was not associated with an increased risk of $\mathrm{CV}$ death or all-cause mortality in the group treated with saxagliptin, a finding that may be considered as reassuring.

Different hypothesis about the mechanisms underlying the increased risk of hospitalization for HF with DPP4 inhibitors were proposed. The higher risk of HF in patients taking these drugs may be related to DPP-4 substrates other than incretin hormones [48]. For example, substance $\mathrm{P}$ is also degraded by DPP-4 and it increases sympathetic activity [53], so there has been concern that elevation of the circulating substance $P$ level by administration of DPP-4 inhibitors may increase the risk of HF by accelerating the heart rate through sympathetic activation [54]. Neuropeptide Y is another peptide degraded by DPP-4, and it also increases sympathetic activity [53]. Accordingly, it is possible that the increased risk of hospitalization for HF may be related to elevation of the plasma levels of DPP-4 substrates such as substance P and/or neuropeptide $\mathrm{Y}$ that stimulate sympathetic activity, and this would represent a class effect of DPP-4 inhibitors. Interestingly, the rate of hospitalization for HF was significantly increased by treatment with saxagliptin throughout the SAVOR trial. However, subanalysis showed that hospitalization for HF was not increased in patients receiving concomitant treatment with beta-blockers, supporting the hypothesis that saxagliptin increased the risk of HF via sympathetic activation [55]. In contrast with this class effect of DPP4-inhibitors, it seems that the renal effects of DPP-4 inhibitors differ between those mainly excreted in the urine and those with low urinary excretion, depending on differential suppression of tubular sodium-hydrogen exchanger 3 (NHE3) activity. Unlike other DPP-4 inhibitors, sitagliptin and alogliptin are mainly excreted in the urine and suppress renal NHE3 activity, promoting natriuresis and reducing the systolic blood pressure too. It could explain why they do not increase the risk of HF in diabetic patients [54].

Nevertheless, caution is recommended and T2DM patients taking saxagliptin should be informed to contact their health professionals in case of symptoms (shortness of breath) and signs (swelling in the ankles) of HF [48].

\section{GLP-1RAs}

GLP-1RAs, introduced in 2005, are either exendin-like peptides (exenatide and lixisenatide) or more homologous GLP-1 analogues, which are structurally adapted and formulated to reduce degradation by DPP-4. Current GLP-1RAs are administered by subcutaneous injection, except for oral semaglutide and act via the GLP-1 receptor to enhance the incretin effect [36].

GLP-1RAs have been associated with a reduction of major CV events (MACE) and mortality on the basis of the results of CV outcome trials (CVOTs) [56].

Recently, a systematic review and meta-analysis included and evaluated all the large, placebo-controlled, CV outcome trials of GLP-1RAs, to obtain robust estimates of the effects of this class of drugs on different $\mathrm{CV}$ outcomes overall and in prespecified patient subgroups, as well as examining kidney outcomes and key safety outcomes [38]. Seven trials with a total of 56004 patients were included in the metaanalysis: ELIXA (lixisenatide) [18], LEADER (liraglutide) [19], SUSTAIN-6 (semaglutide) [20], EXSCEL (exenatide) [27], Harmony Outcomes (albiglutide) [28], REWIND (dulaglutide) [29], and PIONEER 6 (oral semaglutide) [57].

In these trials, the proportion of patients with established $\mathrm{CV}$ disease at baseline ranged from $100 \%$ in ELIXA and Harmony Outcomes to $31 \%$ of those in REWIND. Kidney function was similar across trials (with median eGFR ranging from 74 to $80 \mathrm{~mL} / \mathrm{min}$ per $\mathrm{m}$ [2]). Median HbA1c was lowest in REWIND and ELIXA (7.1\% and 7.7\%, respectively) and highest in LEADER, SUSTAIN-6, and Harmony Outcomes (8.7\%). In the pooled analysis, treatment with a GLP-1RAs led to a $12 \%$ relative risk reduction in MACE (HR 0.88, 95\% CI 0.82-0.94; $P<0.0001$ ); Fig. 4). The NNT to prevent one MACE event was 75 (95\% CI 50-151) over an estimated median follow-up of 3.2 years. When assessing the components of the composite MACE outcome separately, GLP-1RA use led to a reduction in risk of death from CV causes (HR 0.88, 95\% CI 0.81-0.96; $P<0.0001$ ), fatal or non-fatal stroke $(0.84,0.76-0.93 ; P<0.0001)$, and fatal or non-fatal MI (0.91, 0.84-1.00; $P=0.043)$; (Fig. 4). In subgroup analyses, there was no statistical heterogeneity between the effect of a GLP-1RAs in primary prevention patients (those without established $\mathrm{CV}$ disease) and in patients with CV disease at baseline: the HR was 0.95 (95\% CI $0.83-1.08)$ for primary prevention and 0.86 $(0.79-0.94)$ for secondary prevention ( $p$ interaction $=0.22$ ). Compared with placebo, treatment with GLP-1RAs reduced the risk of death from any cause by $12 \%$ (HR $0.88,95 \% \mathrm{CI}$ $0.83-0.95 ; P=0.001$ ), with an NNT to prevent one death of 108 (77-260) over an estimated median follow-up of 


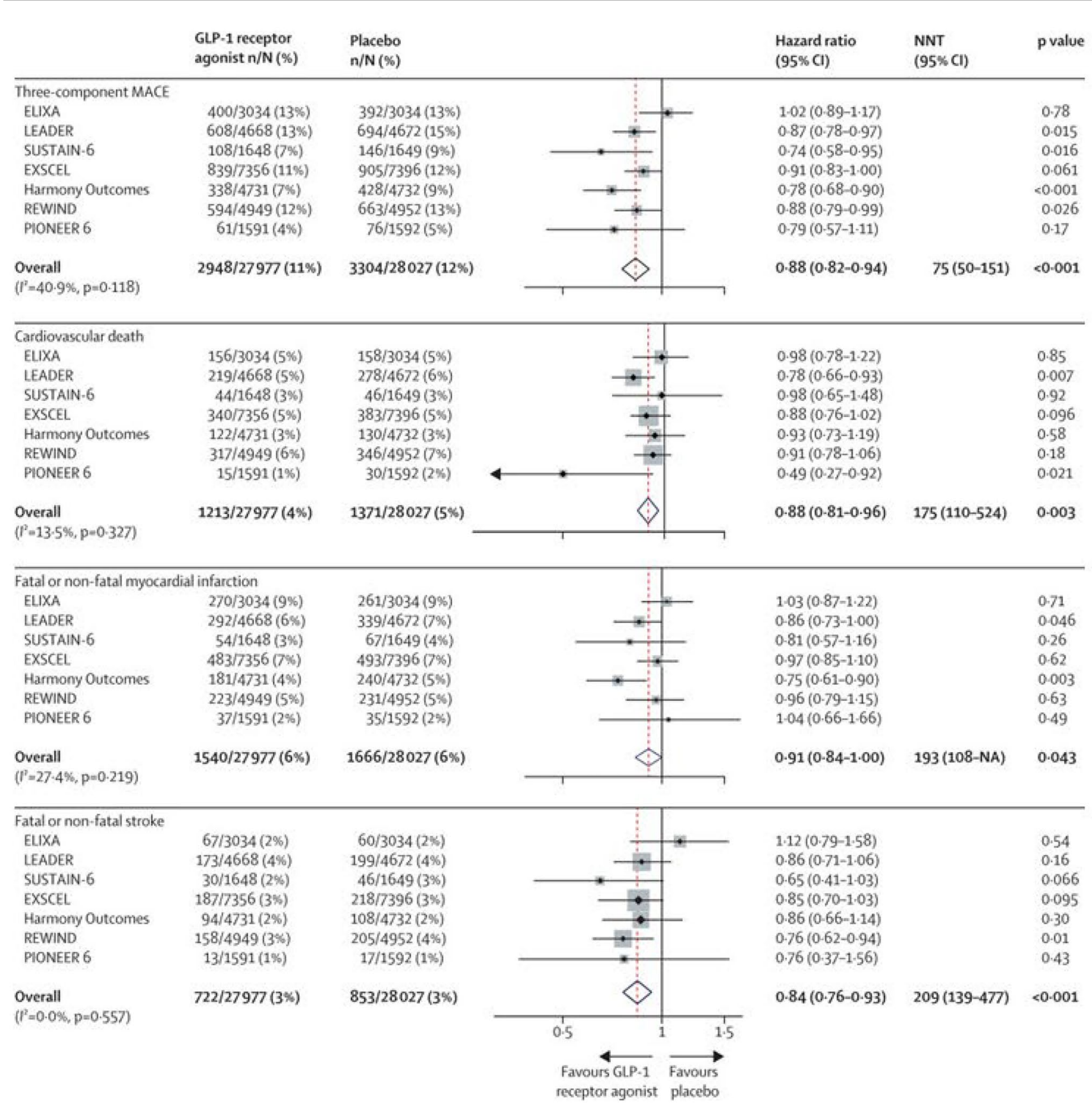

Fig. 4 Risk of MACE and each of its components in the seven CV outcome trials of GLP-1 receptor agonists [38]

3.2 years. Furthermore, treatment with GLP-1RAs reduced the broader composite kidney outcome (development of macroalbuminuria, worsening kidney function [doubling of serum creatinine or $40 \%$ or greater decline in eGFR], end-stage kidney disease, and kidney-related death) by $17 \%$ (HR 0.83, 95\% CI 0.78-0.89), with an NNT to prevent one event of 62 (48-96) over the estimated median follow-up of 3.2 years. This finding was mainly due to a reduction in urinary albumin excretion.
Based on these data, it can be considered that in patients with T2DM, GLP-1RAs reduced three-component MACE and each component, as well as all-cause mortality, but had little or no effect on hospitalization for HF [58]. Treatment with a GLP-1RAs also reduced the risk of worsening kidney function, due mainly to a decrease in development of macroalbuminuria. These benefits were obtained without an increase in risk of severe hypoglycaemia, pancreatic adverse effects, or thyroid cancer. 


\section{SGLT2i}

Introduced in 2012, the sodium-glucose cotransporter-2 inhibitors are widely used as second and third line of glucose-lowering agents, with low risk of hypoglycaemia plus weight-lowering and blood pressure lowering effects. Their insulin-independent glycosuric action differs from other glucose-lowering agents enabling use in combination with any other class of drug at any stage in the natural history of T2DM, if there is adequate renal function [36].

Across a broad sample of patients with cardiometabolic and kidney disease, SGLT2i therapy results in moderate reductions in all-cause mortality, CV mortality, and MI, and substantial reductions in hospitalization for $\mathrm{HF}$ and in adverse kidney outcomes [30]. The magnitude of these effects was largely consistent irrespective of the presence of T2DM, HF, and CKD, and in the majority of cases, there was minimal heterogeneity for clinical endpoints across trials [39].

Recently, a systematic review and meta-analysis about the effect of SGLT2i on CV and kidney outcomes among patients with T2DM, and independent of glycaemic status, among patients with HF and CKD was performed, to analyze data from existing large-scale $\mathrm{CV}$ and kidney outcome trials of SGLT2i and to determine more reliable estimates of efficacy and safety, across the different populations studied [39]. The main outcomes of interest were all-cause mortality, CV mortality, hospitalization for HF, MI, stroke, and kidney outcome, which was defined as the composite of end-stage kidney disease, a doubling of the serum creatinine level, or kidney-related mortality.

A total of 8 RCTs [21-23, 26, 59-68] with 59,747 participants were included; 33,153 of these participants were in the SGLT2i group, whereas 26,594 participants were in the placebo group. Three RCTs investigated dapagliflozin, three RCTs investigated canagliflozin (the two trials from the CANVAS Program: CANVAS and CANVAS-R), two RCTs investigated empagliflozin, and one RCT investigated ertugliflozin. Five of the RCTs were exclusively in patients with T2DM, whereas two included patients with HFrEF regardless of T2DM status.

These systematic review and meta-analysis showed that the use of SGLT2i resulted in a $16 \%$ reduction in the risk of all-cause mortality, $16 \%$ reduction in the risk of $\mathrm{CV}$ mortality, $31 \%$ reduction in the risk of hospitalization for HF, $9 \%$ reduction in the risk of MI, and 38\% reduction in the risk of the composite kidney outcome in all patients (in both patients with and without diabetes). In subgroup analyses stratified by diabetes and HF status, the use of SGLT2i consistently decreased the risk of hospitalization for HF and composite kidney outcome among all subgroups (i.e., patients with T2DM regardless of the HF status, patients with concurrent T2DM and HF, patients with T2DM without $\mathrm{HF}$, and patients with HF regardless of the T2DM status).
SGLT2i therapy had the greatest magnitude of risk reduction of hospitalization for HF and kidney-related outcomes. Importantly, while the use of SGLT2 $i$ was associated with a greater risk of adverse clinical events, the overall incidence was very low [39] (Fig. 5).

Adverse effects linked to SGLT2i are severe genitourinary infections, diabetic ketoacidosis, and amputations [69]. With a small absolute number of events, the meta-analysis found an increased risk of diabetic ketoacidosis and genital infection associated with the use of SGLT2i. The risk of hypoglycaemia and amputations did not differ between SGLT2i and placebo. Despite these excess risks, SGLT2i have an overall favourable safety profile [39].

Recently, in a meta-analysis of the DAPA-HF and EMPEROR-Reduced trials, Zannad et al. demonstrated that the use of SGLT2i in patients with HFrEF reduces the risk of all-cause mortality, CV mortality, and first hospitalization for HF and improves kidney outcomes [70].

More recently sotagliflozin, an SGLT2 $\mathrm{i}$ that also provides some gastrointestinal SGLT1 inhibition, was tested soon after an episode of decompensated HF [71]. The rationale was that SGLT2 inhibition increases glucose excretion in the urine, whereas SGLT1 inhibition reduces the postprandial glucose level by delaying intestinal glucose absorption.

A multicenter, double-blind trial, in patients with T2DM, who were recently hospitalized for worsening HF, was performed. Patients were randomly assigned to receive sotagliflozin or placebo. The primary end point was the total number of deaths from CV causes and hospitalizations and urgent visits for HF (first and subsequent events). Sotagliflozin therapy, initiated before or shortly after discharge, resulted in a significantly lower total number of deaths from $\mathrm{CV}$ causes and hospitalizations and urgent visits for HF than placebo, but the trial ended early because of loss of funding from the sponsor and difficulties due to SARS-COV-2 pandemic [71].

Sotagliflozin was tested in patients with T2DM, CKD, and risks for $\mathrm{CV}$ disease too, resulting in a lower risk of the composite of deaths from $\mathrm{CV}$ causes, hospitalizations for $\mathrm{HF}$, and urgent visits for HF than placebo, but was associated with an increase of adverse events. In particular, diarrhoea, genital mycotic infections, volume depletion, and diabetic ketoacidosis were more common with sotagliflozin than with placebo [72].

The improvement in CV and kidney outcomes, in patients with and without diabetes treated with SGLT2i, suggests inherent cardioprotective and kidney protective properties. Although all patients (regardless of the T2DM status) had improved CV outcomes with the use of SGLT2i, it remains unclear what subgroup of non-diabetic patients would benefit the most from such treatment [39].

Based on such recent evidences, SGLT2i gained relevance in the pharmacological treatment of HFrEF. In particular, dapagliflozin and empagliflozin were included in the 2021 


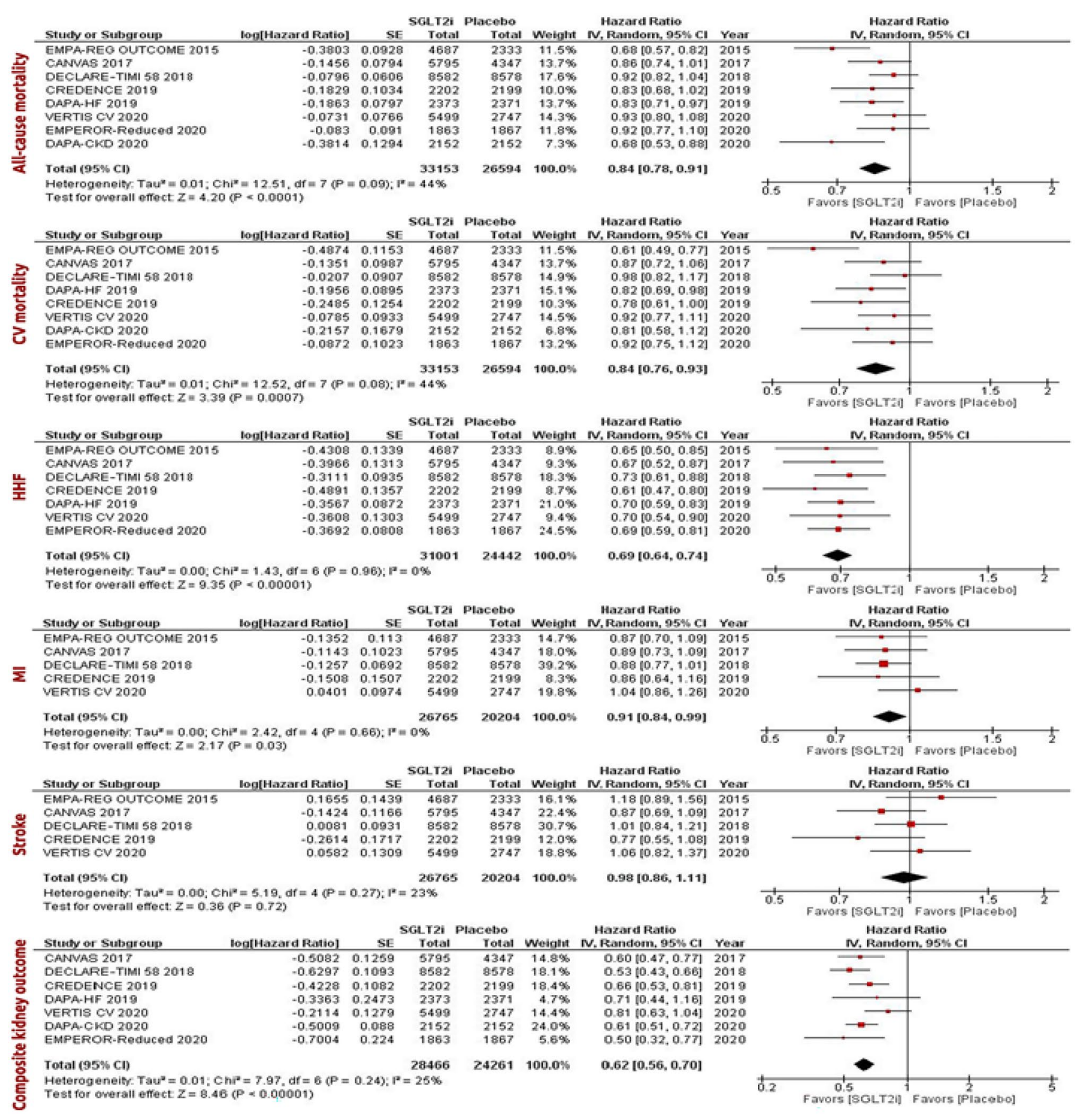

Fig. 5 Forest plots examining the cardiovascular and kidney outcomes in all patients regardless of the type 2 diabetes and heart failure status [39]. CV, cardiovascular; HHF, hospitalization for heart failure; MI, myocardial infarction; IV, inverse variance

European Society of Cardiology HF Guidelines [73] and now are recommended, in addition to optimized medical therapy with ACEi/ARNI, beta-blockers, and MRAs, for all patients with HFrEF regardless of diabetic status (Class I, Level A) to reduce the risk of hospitalization for $\mathrm{HF}$ and death. Moreover, it is expected that the diuretic/natriuretic properties of SGLT2 inhibitors may offer additional benefits in reducing congestion and may allow a reduction in loop diuretic requirement [73].
Regarding heart failure with preserved ejection fraction (HFpEF), an important contribute derived from the results of the The Empagliflozin Outcome Trial in Patients with Chronic Heart Failure with Preserved Ejection Fraction (EMPERORPreserved), presented in the last congress of European Society of Cardiology [74]. In this randomized, double-blind, parallelgroup, placebo-controlled, event-driven trial, empagliflozin was tested in 5988 diabetic and non-diabetic patients with 
chronic HF, NYHA functional classes II-IV, and a left ventricular ejection fraction $>40 \%$. They were randomly assigned to receive empagliflozin (10 $\mathrm{mg}$ once daily) or placebo, in addition to usual medical therapy. The primary outcome was a composite of $\mathrm{CV}$ death or hospitalization for $\mathrm{HF}$, analyzed as the time to the first event. The first secondary outcome was the occurrence of all adjudicated hospitalizations for HF, including first and recurrent events.

Over a median of 26.2 months, a primary outcome event occurred in 415 of 2997 patients (13.8\%) in the empagliflozin group and in 511 of 2991 patients $(17.1 \%)$ in the placebo group (hazard ratio, $0.79 ; 95 \% \mathrm{CI}, 0.69$ to 0.90 ; $P<0.001)$. This effect was mainly related to a lower risk of hospitalization for HF in the empagliflozin group. The effects of empagliflozin appeared consistent in patients with or without diabetes and across prespecified ejection fraction subgroups. The total number of hospitalizations for HF was lower in the empagliflozin group than in the placebo group (407 with empagliflozin and 541 with placebo; hazard ratio, $0.73 ; 95 \%$ CI, 0.61 to $0.88 ; P<0.001)$ [74].

These results may represent a revolution in pharmacological treatment of HFpEF, regardless of the diabetic status. Further confirmations from an ongoing trial with dapagliflozin [75] are needed to consider SGLT2i indicated also in HFpEF patients.

\section{The rationale for redefining diabetes mellitus treatment}

New antidiabetic drugs, particularly GLP-1RAs and SGLT2i, have shown to have metabolic effects beyond reducing plasma glucose levels, this aspect can be the rationale for the paradigm shift in diabetes mellitus treatment.

SGLT2i and GLP-1RAs both lowered the risk of MACE, hospitalization for HF, and renal events. But SGLT2i reduced CV and all-cause mortality, hospitalization for HF, and renal events, the most among the three antidiabetic drug classes. DPP-4 inhibitors showed a similar safety profile to placebo, and it be considered inferior to GLP-1RAs and SGLT2i with respect to CV events and deaths.

Among GLP-1RAs, it has been observed that liraglutide reduces postprandial glucose without increasing insulin concentration and improves beta-cell function in T2DM patients. Its $\mathrm{CV}$ protective effects could be related to reduction in arterial stiffness, LV myocardial strain, twisting and untwisting, $\mathrm{N}$-terminal pro-brain natriuretic peptide, and oxidative stress. These effects could offer myocardial protection and prevention of diabetic heart disease [76]. Moreover, liraglutide reduces postprandial non-esterified free fatty acids and suppresses soluble vascular cell adhesion molecule-1 compared to metformin [77]. It protects against acute liver injury in the mouse [78]. It has been observed that postoperative intravenous exenatide in low-risk patients undergoing scheduled coronary artery bypass grafting surgery, provided no additional cardio-protective effect compared to intravenous insulin [79]. Therefore, it is still necessary to study the CV efficacy and safety profile of GLP-1RAs to confirm their place in clinical practice [80].

Among SGLT2i, the exact mechanism by which they exert the cardioprotective effect is not well understood. Mechanistically, it is assumed that there may be differences between a drug effect (as seen with the significant heterogeneity in mortality data) and a class effect (with the absence of heterogeneity in hospitalization for HF and MI, irrespective of the subgroup) [39].

The hypothesized pharmacological effects of SGLT2i are summarized in Fig. 6 [81].

Several hypotheses attempt to explain the cardio-renal protective effect of SGLT2i:

(1) SGLT2i act on SGLT2 receptor in the proximal kidney tubules, preventing the reabsorption of glucose and sodium. Whether the resultant diuretic effect is the primary driver of the predominant HF and kidney benefits or related to inherent cardioprotective/kidney protective properties associated with SGLT2i use, remains to be clarified [39].

(2) SGLT2i induces a nutrient-deprived state through lower serum glucose levels. The fasting state induces lipolysis in adipose tissue with subsequent generation of ketone bodies, such as $\beta$-hydroxybutyrate. Through an altered substrate utilization and cellular signalling with decreased cellular stress and cellular sodium influx, SGLT2i could promote some of its cardioprotective effects [39].

(3) Although the exact mechanism is still unknown, SGLT2i increased erythropoietin, haemoglobin, and hematocrit levels. This can improve tissue oxygenation, including cardiac tissue, leading to a cardioprotective effect.

(4) Lastly, SGLT2i may indirectly provide a cardioprotective effect by improving the lipid profile and decreasing uric acid levels. The discrepancy between the benefit observed for the most of CV events (death, hospitalization for $\mathrm{HF}$, and $\mathrm{MI}$ ) and no benefit for stroke prevention suggests that some of the mechanisms are limited to specific anatomical districts and systemic effects might not translate into meaningful cerebral protection [39].

The protective mechanism of SGLT2i on the CV system involves many aspects, including direct and indirect effects on the heart [82].

The direct effects include the following:

(1) inhibition of myocardial $\mathrm{Na}^{+} / \mathrm{H}^{+}$exchange (NHE). By inhibiting cardiac $\mathrm{Na}^{+} / \mathrm{H}^{+}$exchange activity, SGLT2i 
Fig. 6 Proposed biological mechanisms and effects of sodium-glucose co-transporter 2 inhibitors [81]

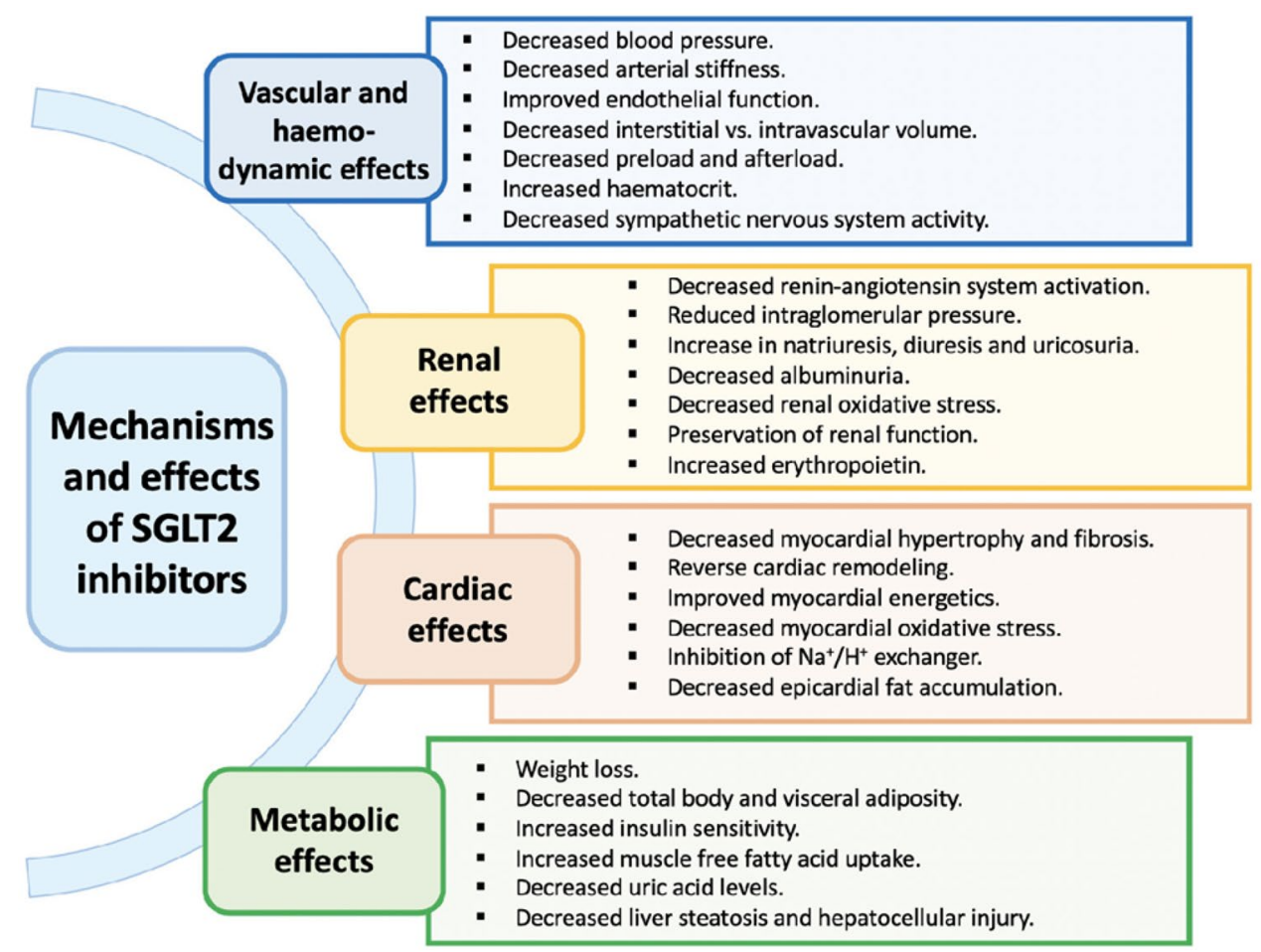

increases the concentration of sodium ions in mitochondria and reverse electrolyte disorders in patients with $\mathrm{HF}$ [82].

(2) improvement of myocardial metabolism. SGLT2i may improve myocardial energy metabolism, increase myocardial oxygen supply, promote ATP energy storage, increase oxygen uptake and transformation at the mitochondrial level, increase ketone bodies, lower the insulin-to-glucagon ratio, inhibit myocardial fibrosis, switch from glucose to ketone utilization during myocardial metabolism, and reverse myocardial remodelling [82].

(3) reduction of cardiac preload. SGLT2i can reduce cardiac preload and myocardial oxygen consumption by osmotic diuresis. More importantly, osmotic diuresis induced by SGLT2 leads to greater electrolyte-free water clearance and subsequently greater fluid clearance from the interstitial fluid space, resulting in congestion relief with minimal impact on blood volume, arterial filling, and organ perfusion [83].

(4) reduction of afterload. SGLT2i can lower blood pressure and afterload by osmotic diuresis and increased urinary sodium excretion, improved $\mathrm{CV}$ function by reducing oxidative stress, and endothelial cell inflammation [82].

(5) reduction of cardiomyocyte apoptosis and myocardial fibrosis. SGLT2i leads to modification of cell apoptosis $[82,84]$. In fact, these agents could influence apoptosis by inducing as well as suppressing it in differing conditions (i.e., cancer vs diabetic milieu). For example, it was observed that empagliflozin can inhibit beta-cell apoptosis via ameliorating glucotoxicity-induced oxidative stress, while dapagliflozin induces apoptotic events and reduces tumour volume in human renal cancer cells and canagliflozin induces remarkable apoptosis processes in human hepatocellular carcinoma cells [84]. SGLT2i could attenuate cardiac fibrosis by alleviating oxidative stress and TGF- $\beta$ production and regulating macrophage polarization too [82]. Interestingly, several studies have demonstrated the relationship between NHE and cardiomyocyte apoptosis [85] and myocardial fibrosis [86, 87]. Active NHE-1 (a predominant isoform of NHE in cardiomyocytes) leads to the accumulation of intracellular sodium, further increasing intracellular $\mathrm{Ca}^{+}$, which triggers myocardial apoptosis in addition to necrosis. A possible link between NHE-1 activity and fibrosis may be secondary to the fact that NHE-1 is a downstream effector of several fibrosis-related signalling systems.

(6) reduction of the synthesis of adipokines, cytokines, and epicardial adipose tissue. The alteration of adipokine production and/or action has been proposed as a common mechanism of $\mathrm{CV}$ disease. Ectopic fat deposition in the form of epicardial fat could lead to the genesis of HF [88]. SGLT2i could restore the balance between pro- and anti-inflammatory adipokines.

(7) modulation of sympathetic nerve activity [89]. Activation of the sympathetic nervous system is closely related to the onset and progression of $\mathrm{HF}$, and the mechanism by which SGLT2i suppress sympathetic nerve activity 
Table 3 Potential mechanisms through which glucagon-like peptide-1 receptor agonists (GLP-1RAs) and sodium/glucose co-transporter-2 (SGLT-2) inhibitors exert cardio- renal protective effects beyond glucose-lowering and weight-lowering effects ${ }^{36}$

\section{GLP-1 receptor agonists}

Cardiovascular Mostly decrease ASCVD

Renal

\section{$\downarrow$ Blood pressure (but $\uparrow$ heart rate)}

$\uparrow$ Vasodilatation (endothelium-mediated?)

$\downarrow$ Angiotensin II (renin activity unchanged?)

$\uparrow$ Natriuresis ( $\downarrow$ renal $\mathrm{Na} / \mathrm{H}$ exchanger?)

$\downarrow$ Improved lipid profile $(\downarrow$ TC, $\downarrow$ LDL,$\downarrow$ TG)

$\downarrow$ Inflammatory and atherothrombotic markers

( $\downarrow$ CRP, $\downarrow$ eNOS,$\downarrow$ ICAM- $1, \downarrow$ PAI- 1 )

Decrease in albuminuria

$\Delta$ Intra-renal haemodynamics (mechanisms unclear)

$\downarrow$ Angiotensin II activity in glomerulus (effect unclear)

$\downarrow$ Inflammation (partly by $\downarrow$ adiposity)

$\downarrow$ Oxidative stress (partly by $\downarrow$ glucotoxicity)

\section{SGLT-2 inhibitors}

$\downarrow$ Blood pressure

$\downarrow$ Plasma volume (due to diuresis)

$\downarrow$ Arterial stiffness (mechanism unclear)

$\uparrow$ Myocardial energy substrate (ketones)

$\uparrow$ Myocardial BCAA catabolism $(\uparrow \mathrm{PDH})$

$\uparrow$ Myocardial energetics ( $\downarrow \mathrm{Na} / \mathrm{H}$ exchanger $\uparrow$ mitochondrial calcium)

$\uparrow$ Angiotensin 1-7 (mechanism unclear)

$\downarrow$ Uric acid ( $\uparrow$ renal urate excretion)

Decrease CKD and albuminuria

$\downarrow$ Intra-glomerular pressure*

$\uparrow$ Tubulo-glomerular feedback

$\downarrow$ Hyperfiltration

$\downarrow$ Inflammation (partly by $\downarrow$ adiposity)

$\downarrow$ Oxidative stress (partly by $\downarrow$ glucotoxicity)

The cardiovascular protection mediated by GLP-1RAs appears to be mostly through a reduction in fatal atherosclerotic events, while the protection mediated by SGLT-2 inhibitors is mostly by a reduction in the onset and progression of heart failure. SGLT- 2 inhibitors can reduce the long-term decline in glomerular filtration rate and reduce the onset and progression of albuminuria, while the renal effects of GLP-1RAs are less pronounced and appear to involve intra-renal haemodynamic adjustments that alter filtration

*A decrease in intra-glomerular pressure is mediated by a combination of reduced plasma volume, reduced blood pressure and increased tubuloglomerular feedback (TGF). TGF is increased by tubular sodium which activates macula densa cells to release ATP which is converted to adenosine. Adenosine causes contraction of afferent glomerular vessels and the reduced intra-glomerular pressure reduces filtration

$\uparrow$ increase, $\downarrow$ decrease, $\Delta$ change

is not yet fully understood. One possible explanation is described by mediating ketone body metabolism.

The indirect effects include the following:

(1) improvement of blood glucose levels. Studies have confirmed that hyperglycosylated haemoglobin and hypoglycaemia events are risk factors for CV events, but SGLT2i can reduce glycosylated haemoglobin lowering the risk of hypoglycaemia and resulting in CV benefits.

(2) promotion of weight loss. Obesity is an independent risk factor for CV disease. SGLT2i causes glycosuria and negative energy balance, thereby leading to body weight loss [90]. SGLT2i can reduce the occurrence of $\mathrm{CV}$ events by promoting weight loss.

(3) reduction of blood pressure [91]. It is well known that hypertension is a common complication of diabetes and one of the risk factors for CV disease. SGLT2i reduces systolic blood pressure (BP) by $2.46 \mathrm{mmHg}$ and diastolic BP by $1.46 \mathrm{mmHg}$, while they reduce 24-h ambulatory systolic and diastolic BP by $3.76 \mathrm{mmHg}$ and $1.83 \mathrm{mmHg}$, respectively. SGLT2i can exert antihypertensive effects in many ways (such as decreased uric acid levels, metabolic fuel switching (ketogenic) activity, reduced body weight, haemodynamic mechanisms secondary to volume depletion caused by diuresis and natriuresis, and so on) and thus play a role in $\mathrm{CV}$ protection.
(4) SGLT2i reduces proteinuria, delaying the progression of renal disease. Proteinuria and renal insufficiency are risk factors for $\mathrm{CV}$ events in patients with diabetes. SGLT2i can reduce proteinuria by reducing glomerular hyperfiltration. In addition, SGLT2i also have a good renal protective effect (described in more detail below), delaying the progressive damage of diabetic nephropathy [82].

The beneficial effects of SGLT2i in preventing CV events have been widely recognized in the clinic, and their possibility to prevent new onset HF in patients without history of HF suggests the intriguing possibility of novel disease modifying effects of the new class of drugs. Probably, SGLT2i affects a variety of pathophysiologic mechanisms in order to explain the prevention of a complex syndrome such as HF [39].

Several mechanisms likely contribute to the kidney protective effect of SGLT2i. By inhibiting SGLT2, less glucose and sodium are reabsorbed in the proximal tubule. The non-reabsorbed glucose and sodium exert an osmotic effect, which increases the fluid delivery to the distal tubule. This, in turn, increases the hydrostatic pressure in Bowman's space. Also, the increase in the delivery of sodium to the macula densa results in vasoconstriction of the afferent arteriolar with a subsequent reduction in the intraglomerular pressure. These changes result in initial reduction in eGFR 
and haemodynamic changes similar to those associated with the use of renin-angiotensin system blockers [39].

The potential mechanisms through which GLP-1RAs and SGLT2i exert cardio-renal protective effects beyond glucose-lowering and weight-lowering effects are illustrated in Table 3.

\section{Conclusions}

The acknowledgment of the disappointing results obtained with therapies aimed exclusively at improving glycaemic control, has led in recent years to a substantial paradigm shift in the treatment of the diabetic patient. The results obtained first with GLP-1RAs and, more recently even more with SGLT2i on mortality and CV events, have made it clear how other mechanisms, beyond the hypoglycaemic effect, are involved in the benefits observed in CVOTs. And as evidence of the great revolution of thought we are experiencing, there is the recognition of gliflozins as drugs for the treatment not only of diabetic patients but also of non-diabetic patients suffering from HF, as reported in the latest ESC/ HFA guidelines. Surely, we still have a lot to understand, but it is certain that this is the beginning of a new era.

Author contribution S. Nodari had the idea for the article and contributed to draft and critically revise the work. F. Fioretti performed the literature search and data analysis and contributed to draft the work. F. Barillà critically revised the work.

\section{References}

1. Rodriguez-Gutierrez R, Gonzalez-Gonzalez JG, Zuñiga-Hernandez JA, McCoy RG (2019) Benefits and harms of intensive glycemic control in patients with type 2 diabetes. BMJ 367. https://doi.org/ 10.1136/BMJ.L5887

2. Stratton IM, Adler AI, Neil HAW, Matthews DR, Manley SE, Cull CA, Hadden D, Turner RC, Holman RR (2000) Association of glycaemia with macrovascular and microvascular complications of type 2 diabetes (UKPDS 35): prospective observational study. BMJ 321(7258):405-412. https://doi.org/10.1136/BMJ.321.7258.405

3. Keiding NR, Root HF, Marble A (1952) Importance of control of diabetes in prevention of vascular complications. J Am Med Assoc 150(10):964-969. https://doi.org/10.1001/JAMA.1952. 03680100006003

4. Hardin RC, Jackson RL, Johnston TL, Kelly HG (1956) The development of diabetic retinopathy: effects of duration and control of diabetes. Diabetes 5(5):397-405. https://doi.org/10.2337/DIAB.5.5.397

5. Group TDC and CTR (2010) The effect of intensive treatment of diabetes on the development and progression of long-term complications in insulin-dependent diabetes mellitus. NEJM 329(14):977986. https://doi.org/10.1056/NEJM199309303291401

6. Turner R, UK Prospective Diabetes Study (UKPDS) Group (1998) Intensive blood-glucose control with sulphonylureas or insulin compared with conventional treatment and risk of complications in patients with type 2 diabetes (UKPDS 33). Lancet 352(9131):837-853. https://doi.org/10.1016/S0140-6736(98) 07019-6
7. American Diabetes Association (2003) Standards of medical care for patients with diabetes mellitus. Diabetes Care 26(Suppl):1. https://doi.org/10.2337/DIACARE.26.2007.S33

8. Clark MJ, Sterrett JJ, Carson DS (2000) Diabetes guidelines: a summary and comparison of the recommendations of the American Diabetes Association, Veterans Health Administration, and American Association of Clinical Endocrinologists. Clin Ther 22(8):899-910. https://doi.org/10.1016/S0149-2918(00) 80063-6

9. Sibal L, Home PD (2009) Management of type 2 diabetes: NICE guidelines. Clin Med (Northfield Il) 9(4):353. https://doi.org/ 10.7861/CLINMEDICINE.9-4-353

10. Miller ME, Williamson JD, Gerstein HC, Byington RP, Cushman WC, Ginsberg HN, Ambrosius WT, Lovato L, Applegate WB, for the ACCORD Investigators, (2013) Effects of randomization to intensive glucose control on adverse events, cardiovascular disease and mortality in older versus younger adults in the ACCORD trial. Diabetes Care 37(3):634-643. https://doi.org/ 10.2337/DC13-1545

11. Vijan S, Sussman JB, Yudkin JS, Hayward RA (2014) Effect of patients' risks and preferences on health gains with plasma glucose level lowering in type 2 diabetes mellitus. JAMA Intern Med 174(8):1227-1234. https://doi.org/10.1001/JAMAINTERNMED. 2014.2894

12. Boussageon R, Bejan-Angoulvant T, Saadatian-Elahi M, Lafont S, Bergeonneau C, Kassaï B, Erpeldinger S, Wright JM, Gueyffier F, Cornu C (2011) Effect of intensive glucose lowering treatment on all-cause mortality, cardiovascular death, and microvascular events in type 2 diabetes: meta-analysis of randomized controlled trials. BMJ 343(7817). https://doi.org/10.1136/BMJ.D4169

13. Hemmingsen B, Lund SS, Gluud C, Vaag A, Almdal T, Hemmingsen C, Wetterslev J (2011) Intensive glycaemic control for patients with type 2 diabetes: systematic review with meta-analysis and trial sequential analysis of randomized clinical trials. BMJ 343(7834):1136. https://doi.org/10.1136/BMJ.D6898

14. Holman RR, Sourij H, Califf RM (2014) Cardiovascular outcome trials of glucose-lowering drugs or strategies in type 2 diabetes. Lancet 383(9933):2008-2017. https://doi.org/10.1016/ S0140-6736(14)60794-7

15. European Medicines Agency (2012) Guideline on clinical investigation of medicinal products in the treatment or prevention of diabetes mellitus. https://www.ema.europa.eu/en/clinical-investigation-medicinalproducts-treatment-prevention-diabetes-mellitus. Published online 29 June 2012.

16. Department of Health and Human Services (2008) Guidance for industry: diabetes mellitus - evaluating cardiovascular risk in new antidiabetic therapies to treat type 2 diabetes. https://www. federalregister.gov/documents/2008/12/19/E8-30086/guidancefor-industry-on-diabetes-mellitus-evaluating-cardiovascular-riskin-new-antidiabetic. Published online 19 December 2008.

17. US Department of Health and Human Services Food and Drug Administration (2008) Guidance for Industry. Diabetes mellitus evaluating cardiovascular risk in new antidiabetic therapies to treat type 2 diabetes. www.fda.gov/downloads/drugs/guidancecomplianceregulatoryinformation/guidances/ucm071627.pdf. Accessed 5 February 2019.

18. Pfeffer MA, Claggett B, Diaz R, Dickstein K, Gerstein HC, Køber LV, Lawson FC, Ping L, Wei X, Lewis EF, Maggioni AP, McMurray JJ, Probstfield JL, Riddle MC, Solomon SD, Tardif JC, Investigators ELIXA (2015) Lixisenatide in patients with type 2 diabetes and acute coronary syndrome. N Engl J Med 373(23):2247-2257. https://doi.org/10.1056/NEJMOA1509225

19. Marso SP, Daniels GH, Brown-Frandsen K, Kristensen P, Mann JF, Nauck MA, Nissen SE, Pocock S, Poulter NR, Ravn LS, Steinberg WM, Stockner M, Zinman B, Bergenstal RM, Buse JB, Steering Committee LEADER, Trial Investigators LEADER (2016) 
Liraglutide and cardiovascular outcomes in type 2 diabetes. NEJM 375(4):311-322. https://doi.org/10.1056/NEJMoa1603827

20. Marso SP, Bain SC, Consoli A, Eliaschewitz FG, Jódar E, Leiter LA, Lingvay I, Rosenstock J, Seufert J, Warren ML, Woo V, Hansen O, Holst AG, Pettersson J, Vilsbøll T, SUSTAIN-6 Investigators (2016) Semaglutide and cardiovascular outcomes in patients with type 2 diabetes. NEJM 375(19):1834-1844. https:// doi.org/10.1056/NEJMOA1607141

21. Neal B, Perkovic V, Mahaffey KW, de Zeeuw D, Fulcher G, Erondu N, Shaw W, Law G, Desai M, Matthews DR, CANVAS Program Collaborative Group (2017) Canagliflozin and cardiovascular and renal events in type 2 diabetes. NEJM 377(7):644657.https://doi.org/10.1056/NEJMOA1611925

22. Perkovic V, de Zeeuw D, Mahaffey KW, Fulcher G, Erondu N, Shaw W, Barrett TD, Weidner-Wells M, Deng H, Matthews DR, Neal B (2018) Canagliflozin and renal outcomes in type 2 diabetes: results from the CANVAS Program randomized clinical trials. Lancet Diabetes Endocrinol 6(9):691-704. https://doi.org/ 10.1016/S2213-8587(18)30141-4

23. Wiviott SD, Raz I, Bonaca MP, Mosenzon O, Kato ET, Cahn A, Silverman MG, Zelniker TA, Kuder JF, Murphy SA, Bhatt DL, Leiter LA, McGuire DK, Wilding JPH, Ruff CT, Gause-Nilsson IAM, Fredriksson M, Johansson PA, Langkilde AM, Sabatine MS; DECLARE-TIMI 58 Investigators (2018) Dapagliflozin and cardiovascular outcomes in type 2 diabetes. NEJM 380(4):347357. https://doi.org/10.1056/NEJMOA1812389

24. Perkovic V, Jardine MJ, Neal B, Bompoint S, Heerspink HJL, Charytan DM, Edwards R, Agarwal R, Bakris G, Bull S, Cannon CP, Capuano G, Chu PL, de Zeeuw D, Greene T, Levin A, Pollock C, Wheeler DC, Yavin Y, Zhang H, Zinman B, Meininger G, Brenner BM, Mahaffey KW, Trial Investigators CREDENCE (2019) Canagliflozin and renal outcomes in type 2 diabetes and nephropathy. NEJM 380(24):22952306. https://doi.org/10.1056/NEJMOA1811744

25. Gerstein HC, Colhoun HM, Dagenais GR, Diaz R, Lakshmanan M, Pais P, Probstfield J, Botros FT, Riddle MC, Rydén L, Xavier D, Atisso CM, Dyal L, Hall S, Rao-Melacini P, Wong G, Avezum A, Basile J, Chung N, Conget I, Cushman WC, Franek E, Hancu N, Hanefeld M, Holt S, Jansky P, Keltai M, Lanas F, Leiter LA, Lopez-Jaramillo P, Cardona Munoz EG, Pirags V, Pogosova N, Raubenheimer PJ, Shaw JE, Sheu WH, Temelkova-Kurktschiev T, Investigators REWIND (2019) Dulaglutide and renal outcomes in type 2 diabetes: an exploratory analysis of the REWIND randomized, placebo-controlled trial. Lancet 394(10193):131-138. https://doi.org/10.1016/S0140-6736(19)31150-X

26. Zinman B, Wanner C, Lachin JM, Fitchett D, Bluhmki E, Hantel S, Mattheus M, Devins T, Johansen OE, Woerle HJ, Broedl UC, Inzucchi SE; Empa-reg outcome Investigators (2015) Empagliflozin, cardiovascular outcomes, and mortality in type 2 diabetes NEJM 13(1):17-18. https://doi.org/10.1056/NEJMOA1504720

27. Holman RR, Bethel MA, Mentz RJ, Thompson VP, Lokhnygina Y, Buse JB, Chan JC, Choi J, Gustavson SM, Iqbal N, Maggioni AP, Marso SP, Öhman P, Pagidipati NJ, Poulter N, Ramachandran A, Zinman B, Hernandez AF; EXSCEL Study Group (2017) Effects of once-weekly exenatide on cardiovascular outcomes in type 2 diabetes. NEJM 377(13):1228-1239. https://doi.org/10.1056/ NEJMOA 1612917

28. Hernandez AF, Green JB, Janmohamed S, D'Agostino RB Sr, Granger CB, Jones NP, Leiter LA, Rosenberg AE, Sigmon KN, Somerville MC, Thorpe KM, McMurray JJV, Del Prato S, Outcomes H, committees and investigators, (2018) Albiglutide and cardiovascular outcomes in patients with type 2 diabetes and cardiovascular disease (Harmony Outcomes): a double-blind, randomized placebo-controlled trial. Lancet 392(10157):1519-1529. https://doi.org/10.1016/S0140-6736(18)32261-X

29. Gerstein HC, Colhoun HM, Dagenais GR, Diaz R, Lakshmanan M, Pais P, Probstfield J, Riesmeyer JS, Riddle MC, Rydén L,
Xavier D, Atisso CM, Dyal L, Hall S, Rao-Melacini P, Wong G, Avezum A, Basile J, Chung N, Conget I, Cushman WC, Franek E, Hancu N, Hanefeld M, Holt S, Jansky P, Keltai M, Lanas F, Leiter LA, Lopez-Jaramillo P, Cardona Munoz EG, Pirags V, Pogosova N, Raubenheimer PJ, Shaw JE, Sheu WH, Temelkova-Kurktschiev T, Investigators REWIND (2019) Dulaglutide and cardiovascular outcomes in type 2 diabetes (REWIND): a double-blind, randomized placebo-controlled trial. Lancet 394(10193):121-130. https://doi.org/10.1016/S0140-6736(19)31149-3

30. Correale M, Petroni R, Coiro S, Antohi EL, Monitillo F, Leone M, Triggiani M, Ishihara S, Dungen HD, Sarwar CMS, Memo M, Sabbah HN, Metra M, Butler J, Nodari S (2021) Paradigm shift in heart failure treatment: are cardiologists ready to use gliflozins? Heart Fail Rev. Epub ahead of print. PMID: 34097173. https://doi. org/10.1007/S10741-021-10107-8

31. ACCORD Study Group, Gerstein HC, Miller ME, Genuth S, Ismail-Beigi F, Buse JB, Goff DC Jr, Probstfield JL, Cushman WC, Ginsberg HN, Bigger JT, Grimm RH Jr, Byington RP, Rosenberg YD, Friedewald WT (2011) Long-term effects of intensive glucose lowering on cardiovascular outcomes. NEJM 364(9):818-828. https://doi.org/10.1056/NEJMOA1006524

32. Coca SG, Ismail-Beigi F, Haq N, Krumholz HM, Parikh CR (2012) Role of intensive glucose control in development of renal end points in type 2 diabetes mellitus: systematic review and meta-analysis. Arch Intern Med 172(10):761-769. https://doi. org/10.1001/ARCHINTERNMED.2011.2230

33. Rawshani A, Rawshani A, Franzén S, Sattar N, Eliasson B, Svensson AM, Zethelius B, Miftaraj M, McGuire DK, Rosengren A, Gudbjörnsdottir S (2018) Risk factors, mortality, and cardiovascular outcomes in patients with type 2 diabetes. NEJM 379(7):633-644. https:// doi.org/10.1056/NEJMOA1800256

34. Control Group, Turnbull FM, Abraira C, Anderson RJ, Byington RP, Chalmers JP, Duckworth WC, Evans GW, Gerstein HC, Holman RR, Moritz TE, Neal BC, Ninomiya T, Patel AA, Paul SK, Travert F, Woodward M (2009) Intensive glucose control and macrovascular outcomes in type 2 diabetes. Diabetol 52(11):2288-2298. https://doi. org/10.1007/S00125-009-1470-0

35. Gilbert RE, Krum H (2015) Heart failure in diabetes: effects of anti-hyperglycaemic drug therapy. Lancet 385(9982):2107-2117. https://doi.org/10.1016/S0140-6736(14)61402-1

36. Bailey CJ, Day C (2019) The future of new drugs for diabetes management. Diabetes Res Clin Pract 155. https://doi.org/10. 1016/J.DIABRES.2019.107785

37. Cosentino F, Grant PJ, Aboyans V, Bailey CJ, Ceriello A, Delgado V, Federici M, Filippatos G, Grobbee DE, Hansen TB, Huikuri HV, Johansson I, Jüni P, Lettino M, Marx N, Mellbin LG, Östgren CJ, Rocca B, Roffi M, Sattar N, Seferović PM, Sousa-Uva M, Valensi P, Wheeler DC; ESC Scientific Document Group (2020) 2019 ESC Guidelines on diabetes, pre-diabetes, and cardiovascular diseases developed in collaboration with the EASD. The Task Force for diabetes, pre-diabetes, and cardiovascular diseases of the European Society of Cardiology (ESC) and the European Association for the Study of Diabetes (EASD). Eur Heart J 41(2):255-323. https://doi. org/10.1093/EURHEARTJ/EHZ486

38. Kristensen SL, Rørth R, Jhund PS, Docherty KF, Sattar N, Preiss D, Køber L, Petrie MC, McMurray JJV (2019) Cardiovascular, mortality, and kidney outcomes with GLP-1 receptor agonists in patients with type 2 diabetes: a systematic review and meta-analysis of cardiovascular outcome trials. Lancet Diabetes Endocrinol 7(10):776-785. https://doi.org/10.1016/S2213-8587(19)30249-9

39. Salah HM, Al'Aref SJ, Khan MS, Al-Hawwas M, Vallurupalli S, Mehta JL, Mounsey JP, Greene SJ, McGuire DK, Lopes RD, Fudim M (2021) Effect of sodium-glucose cotransporter 2 inhibitors on cardiovascular and kidney outcomes-systematic review and meta-analysis of randomized placebo-controlled trials. Am Heart J 232:10-22. https://doi.org/10.1016/J.AHJ.2020.10.064 
40. Elgendy IY, Mahmoud AN, Barakat AF, Elgendy AY, Saad M, Abuzaid A, Wayangankar SA, Bavry AA (2016) Cardiovascular safety of dipeptidyl-peptidase IV inhibitors: a meta-analysis of placebo-controlled randomized trials. Am J Cardiovasc Drugs 17(2):143-155. https://doi.org/10.1007/S40256-016-0208-X

41. McInnes G, Evans M, Del Prato S, Stumvoll M, Schweizer A, Lukashevich V, Shao Q, Kothny W (2015) Cardiovascular and heart failure safety profile of vildagliptin: a meta-analysis of 17 000 patients. Diabetes, Obes Metab 17(11):1085-1092. https:// doi.org/10.1111/DOM.12548

42. Savarese G, D'Amore C, Federici M, De Martino F, Dellegrottaglie S, Marciano C, Ferrazzano F, Losco T, Lund LH, Trimarco B, Rosano GM, Perrone-Filardi P (2016) Effects of dipeptidyl peptidase 4 inhibitors and sodium-glucose linked cotransporter-2 inhibitors on cardiovascular events in patients with type 2 diabetes mellitus: a meta-analysis. Int J Cardiol 220:595-601. https://doi.org/10.1016/J. IJCARD.2016.06.208

43. Bailey CJ, Marx N (2019) Cardiovascular protection in type 2 diabetes: insights from recent outcome trials. Diabetes, Obes Metab 21(1):3-14. https://doi.org/10.1111/DOM.13492

44. White WB, Pratley R, Fleck P, Munsaka M, Hisada M, Wilson C, Menon V (2013) Cardiovascular safety of the dipetidyl peptidase-4 inhibitor alogliptin in type 2 diabetes mellitus. Diabetes, Obes Metab 15(7):668-673. https://doi.org/10.1111/DOM.12093

45. Iqbal N, Parker A, Frederich R, Donovan M, Hirshberg B (2014) Assessment of the cardiovascular safety of saxagliptin in patients with type 2 diabetes mellitus: pooled analysis of 20 clinical trials. Cardiovasc Diabetol 131 13(1):1-9. https://doi.org/10.1186/ 1475-2840-13-33

46. Engel SS, Golm GT, Shapiro D, Davies MJ, Kaufman KD, Goldstein BJ (2013) Cardiovascular safety of sitagliptin in patients with type 2 diabetes mellitus: a pooled analysis. Cardiovasc Diabetol 12(1):1-11. https://doi.org/10.1186/1475-2840-12-3

47. Johansen OE, Neubacher D, von Eynatten M, Patel S, Woerle H-J (2012) Cardiovascular safety with linagliptin in patients with type 2 diabetes mellitus: a pre-specified, prospective, and adjudicated meta-analysis of a phase 3 programme. Cardiovasc Diabetol 11(1):1-10. https://doi.org/10.1186/1475-2840-11-3

48. Scheen AJ (2018) Cardiovascular effects of new oral glucoselowering agents. Circ Res 122(10):1439-1459. https://doi.org/10. 1161/CIRCRESAHA.117.311588

49. Xu S, Zhang X, Tang L, Zhang F, Tong N (2016) Cardiovascular effects of dipeptidyl peptidase-4 inhibitor in diabetic patients with and without established cardiovascular disease: a meta-analysis and systematic review. Postgrad Med 129(2):205-215. https://doi. org/10.1080/00325481.2017.1255537

50. Mahmoud AN, Saad M, Mansoor H, Elgendy AY, Barakat AF, Abuzaid A, Mentias A, Elgendy IY (2017) Cardiovascular safety of incretin-based therapy for type 2 diabetes: a meta-analysis of randomized trials. Int J Cardiol 230:324-326. https://doi.org/10. 1016/J.IJCARD.2016.12.113

51. Abbas AS, Dehbi H-M, Ray KK (2016) Cardiovascular and noncardiovascular safety of dipeptidyl peptidase-4 inhibition: a metaanalysis of randomized controlled cardiovascular outcome trials. Diabetes, Obes Metab 18(3):295-299. https://doi.org/10.1111/ DOM.12595

52. Scirica BM, Bhatt DL, Braunwald E, Steg PG, Davidson J, Hirshberg B, Ohman P, Frederich R, Wiviott SD, Hoffman EB, Cavender MA, Udell JA, Desai NR, Mosenzon O, McGuire DK, Ray KK, Leiter LA, Raz I; SAVOR-TIMI 53 Steering Committee and Investigators (2013) Saxagliptin and cardiovascular outcomes in patients with type 2 diabetes mellitus. NEJM 369(14):1317-1326.https://doi.org/ 10.1056/NEJMOA1307684

53. Shanks J, Herring N (2013) Peripheral cardiac sympathetic hyperactivity in cardiovascular disease: role of neuropeptides. Am J
Physiol Regul Integr Comp Physiol 305(12):1411-1420. https:// doi.org/10.1152/AJPREGU.00118.2013

54. Sano M (2019) Mechanism by which dipeptidyl peptidase-4 inhibitors increase the risk of heart failure and possible differences in heart failure risk. J Cardiol 73(1):28-32. https://doi.org/10.1016/J. JJCC.2018.07.004

55. Scirica BM, Braunwald E, Raz I, Cavender MA, Morrow DA, Jarolim P, Udell JA, Mosenzon O, Im K, Umez-Eronini AA, Pollack PS, Hirshberg B, Frederich R, Lewis BS, McGuire DK, Davidson J, Steg PG, Bhatt DL, SAVOR-TIMI 53 Steering Committee and Investigators (2014) Heart failure, saxagliptin, and diabetes mellitus: observations from the SAVOR-TIMI 53 randomized trial. Circulation 130(18):1579-1588. https://doi.org/10. 1161/CIRCULATIONAHA.114.010389

56. Nreu B, Dicembrini I, Tinti F, Sesti G, Mannucci E, Monami M (2020) Major cardiovascular events, heart failure, and atrial fibrillation in patients treated with glucagon-like peptide-1 receptor agonists: an updated meta-analysis of randomized controlled trials. Nutr Metab Cardiovasc Dis 30(7):1106-1114. https://doi. org/10.1016/J.NUMECD.2020.03.013

57. Husain M, Birkenfeld AL, Donsmark M, Dungan K, Eliaschewitz FG, Franco DR, Jeppesen OK, Lingvay I, Mosenzon O, Pedersen SD, Tack CJ, Thomsen M, Vilsbøll T, Warren ML, Bain SC; PIONEER 6 Investigators (2019) Oral semaglutide and cardiovascular outcomes in patients with type 2 diabetes. NEJM 381(9):841851.https://doi.org/10.1056/NEJMOA1901118

58. Palmer SC, Tendal B, Mustafa RA, Vandvik PO, Li S, Hao Q, Tunnicliffe D, Ruospo M, Natale P, Saglimbene V, Nicolucci A, Johnson DW, Tonelli M, Rossi MC, Badve SV, Cho Y, NadeauFredette AC, Burke M, Faruque LI, Lloyd A, Ahmad N, Liu Y, Tiv S, Millard T, Gagliardi L, Kolanu N, Barmanray RD, McMorrow R, Raygoza Cortez AK, White H, Chen X, Zhou X, Liu J, Rodríguez AF, González-Colmenero AD, Wang Y, Li L, Sutanto S, Solis RC, Díaz González-Colmenero F, Rodriguez-Gutierrez R, Walsh M, Guyatt G, Strippoli GFM (2021) Sodium-glucose cotransporter protein-2 (SGLT-2) inhibitors and glucagon-like peptide-1 (GLP-1) receptor agonists for type 2 diabetes: systematic review and network meta-analysis of randomized controlled trials. BMJ 372. https://doi.org/10.1136/BMJ.M4573

59. Neuen BL, Ohkuma T, Neal B, Matthews DR, de Zeeuw D, Mahaffey KW, Fulcher G, Desai M, Li Q, Deng H, Rosenthal N, Jardine MJ, Bakris G, Perkovic V (2018) Cardiovascular and renal outcomes with canagliflozin according to baseline kidney function. Circulation 138(15):1537-1550. https://doi.org/10.1161/ CIRCULATIONAHA.118.035901

60. Cannon CP, Pratley R, Dagogo-Jack S, Mancuso J, Huyck S, Masiukiewicz U, Charbonnel B, Frederich R, Gallo S, Cosentino F, Shih WJ, Gantz I, Terra SG, Cherney DZI, McGuire DK, Investigators VERTISCV (2020) Cardiovascular outcomes with ertugliflozin in type 2 diabetes. NEJM 383(15):1425-1435. https://doi. org/10.1056/NEJMOA2004967

61. Heerspink HJL, Stefánsson BV, Correa-Rotter R, Chertow GM, Greene T, Hou FF, Mann JFE, McMurray JJV, Lindberg M, Rossing P, Sjöström CD, Toto RD, Langkilde AM, Wheeler DC, Trial Committees DAPA-CKD, Investigators, (2020) Dapagliflozin in patients with chronic kidney disease. NEJM 383(15):1436-1446. https://doi. org/10.1056/NEJMOA2024816

62. Wanner C, Lachin JM, Inzucchi SE, Fitchett D, Mattheus M, George J, Woerle HJ, Broedl UC, von Eynatten M, Zinman B, Investigators EMPA-REGOUTCOME (2018) Empagliflozin and clinical outcomes in patients with type 2 diabetes mellitus, established cardiovascular disease, and chronic kidney disease. Circulation 137(2):119-129. https://doi.org/10.1161/CIRCULATIONAHA. 117.028268

63. McMurray JJV, Solomon SD, Inzucchi SE, Køber L, Kosiborod MN, Martinez FA, Ponikowski P, Sabatine MS, Anand IS, 
Bělohlávek J, Böhm M, Chiang CE, Chopra VK, de Boer RA, Desai AS, Diez M, Drozdz J, Dukát A, Ge J, Howlett JG, Katova T, Kitakaze M, Ljungman CEA, Merkely B, Nicolau JC, O'Meara E, Petrie MC, Vinh PN, Schou M, Tereshchenko S, Verma S, Held C, DeMets DL, Docherty KF, Jhund PS, Bengtsson O, Sjöstrand M, Langkilde AM, Trial Committees DAPA-HF, Investigators, (2019) Dapagliflozin in patients with heart failure and reduced ejection fraction. NEJM 381(21):1995-2008. https://doi.org/10. 1056/NEJMOA1911303

64. Packer M, Anker SD, Butler J, Filippatos G, Pocock SJ, Carson P, Januzzi J, Verma S, Tsutsui H, Brueckmann M, Jamal W, Kimura K, Schnee J, Zeller C, Cotton D, Bocchi E, Böhm M, Choi DJ, Chopra V, Chuquiure E, Giannetti N, Janssens S, Zhang J, Gonzalez Juanatey JR, Kaul S, Brunner-La Rocca HP, Merkely B, Nicholls SJ, Perrone S, Pina I, Ponikowski P, Sattar N, Senni M, Seronde MF, Spinar J, Squire I, Taddei S, Wanner C, Zannad F, EMPERORReduced Trial Investigators, (2020) Cardiovascular and renal outcomes with empagliflozin in heart failure. NEJM 383(15):14131424. https://doi.org/10.1056/NEJMOA2022190

65. Petrie MC, Verma S, Docherty KF, Inzucchi SE, Anand I, Belohlávek J, Böhm M, Chiang CE, Chopra VK, de Boer RA, Desai AS, Diez M, Drozdz J, Dukát A, Ge J, Howlett J, Katova T, Kitakaze M, Ljungman CEA, Merkely B, Nicolau JC, O’Meara E, Vinh PN, Schou M, Tereshchenko S, Køber L, Kosiborod MN, Langkilde AM, Martinez FA, Ponikowski P, Sabatine MS, Sjöstrand M, Solomon SD, Johanson P, Greasley PJ, Boulton D, Bengtsson O, Jhund PS, McMurray JJV (2020) Effect of dapagliflozin on worsening heart failure and cardiovascular death in patients with heart failure with and without diabetes. JAMA 323(14):1353-1368. https://doi.org/10.1001/JAMA. 2020.1906

66. Rådholm K, Figtree G, Perkovic V, Solomon SD, Mahaffey KW, de Zeeuw D, Fulcher G, Barrett TD, Shaw W, Desai M, Matthews DR, Neal B (2018) Canagliflozin and heart failure in type 2 diabetes mellitus. Circulation 138(5):458-468. https://doi.org/10.1161/ CIRCULATIONAHA.118.034222

67. Mahaffey KW, Jardine MJ, Bompoint S, Cannon CP, Neal B, Heerspink HJL, Charytan DM, Edwards R, Agarwal R, Bakris G, Bull S, Capuano G, de Zeeuw D, Greene T, Levin A, Pollock C, Sun T, Wheeler DC, Yavin Y, Zhang H, Zinman B, Rosenthal N, Brenner BM, Perkovic V (2019) Canagliflozin and cardiovascular and renal outcomes in type 2 diabetes mellitus and chronic kidney disease in primary and secondary cardiovascular prevention groups. Circulation 140(9):739-750. https://doi.org/10.1161/ CIRCULATIONAHA.119.042007

68. Fitchett D, Zinman B, Wanner C, Lachin JM, Hantel S, Salsali A, Johansen OE, Woerle HJ, Broedl UC, Inzucchi SE, EMPA-REG OUTCOME trial investigators, (2016) Heart failure outcomes with empagliflozin in patients with type 2 diabetes at high cardiovascular risk: results of the EMPA-REG OUTCOME trial. Eur Heart J 37(19):1526-1534. https://doi.org/10.1093/EURHEARTJ/ EHV728

69. Pittampalli S, Upadyayula S, Mekala HM, Lippmann S (2018) Risks vs benefits for SGLT2 inhibitor medications. Fed Pract 35(7):45. https://www.ncbi.nlm.nih.gov/pmc/articles/PMC6368009. Accessed 24 July 2021. PMID: 30766374

70. Zannad F, Ferreira JP, Pocock SJ, Anker SD, Butler J, Filippatos G, Brueckmann M, Ofstad AP, Pfarr E, Jamal W, Packer M (2020) SGLT2 inhibitors in patients with heart failure with reduced ejection fraction: a meta-analysis of the EMPEROR-Reduced and DAPA-HF trials. Lancet 396(10254):819-829. https://doi.org/ 10.1016/S0140-6736(20)31824-9

71. Bhatt DL, Szarek M, Steg PG, Cannon CP, Leiter LA, McGuire DK, Lewis JB, Riddle MC, Voors AA, Metra M, Lund LH, Komajda M, Testani JM, Wilcox CS, Ponikowski P, Lopes RD, Verma S, Lapuerta P, Pitt B, Trial Investigators SOLOIST-WHF (2020)
Sotagliflozin in patients with diabetes and recent worsening heart failure. NEJM 384(2):117-128. https://doi.org/10.1056/NEJMOA2030183

72. Bhatt DL, Szarek M, Pitt B, Cannon CP, Leiter LA, McGuire DK, Lewis JB, Riddle MC, Inzucchi SE, Kosiborod MN, Cherney DZI, Dwyer JP, Scirica BM, Bailey CJ, Díaz R, Ray KK, Udell JA, Lopes RD, Lapuerta P, Steg PG, Investigators SCORED (2020) Sotagliflozin in patients with diabetes and chronic kidney disease. NEJM 384(2):129-139. https://doi.org/10.1056/NEJMOA2030186

73. McDonagh TA, Metra M, Adamo M, Gardner RS, Baumbach A, Böhm M, Burri H, Butler J, Čelutkienė J, Chioncel O, Cleland JGF, Coats AJS, Crespo-Leiro MG, Farmakis D, Gilard M, Heymans S, Hoes AW, Jaarsma T, Jankowska EA, Lainscak M, Lam CSP, Lyon AR, McMurray JJV, Mebazaa A, Mindham R, Muneretto C, Francesco Piepoli M, Price S, Rosano GMC, Ruschitzka F, Kathrine Skibelund A; ESC Scientific Document Group (2021) 2021 ESC Guidelines for the diagnosis and treatment of acute and chronic heart failure. Eur Heart J 42(36):3599-3726. https://doi.org/10.1093/eurhe artj/ehab368.PMID: 34447992

74. Anker SD, Butler J, Filippatos G, Ferreira JP, Bocchi E, Böhm M, Brunner-La Rocca HP, Choi DJ, Chopra V, Chuquiure-Valenzuela E, Giannetti N, Gomez-Mesa JE, Janssens S, Januzzi JL, GonzalezJuanatey JR, Merkely B, Nicholls SJ, Perrone SV, Piña IL, Ponikowski P, Senni M, Sim D, Spinar J, Squire I, Taddei S, Tsutsui H, Verma S, Vinereanu D, Zhang J, Carson P, Lam CSP, Marx N, Zeller C, Sattar N, Jamal W, Schnaidt S, Schnee JM, Brueckmann M, Pocock SJ, Zannad F, Packer M, EMPEROR-Preserved Trial Investigators, (2021) Empagliflozin in heart failure with a preserved ejection fraction. NEJM 385(16):1451-1461. https://doi.org/10. 1056/NEJMOA2107038

75. Solomon SD, de Boer RA, DeMets D, Hernandez AF, Inzucchi SE, Kosiborod MN, Lam CSP, Martinez F, Shah SJ, Lindholm D, Wilderäng U, Öhrn F, Claggett B, Langkilde AM, Petersson M, McMurray JJV (2021) Dapagliflozin in heart failure with preserved and mildly reduced ejection fraction: rationale and design of the DELIVER trial. Eur J Heart Fail 23(7):1217-1225. https:// doi.org/10.1002/ejhf.2249

76. Lambadiari V, Pavlidis G, Kousathana F, Varoudi M, Vlastos D, Maratou E, Georgiou D, Andreadou I, Parissis J, Triantafyllidi H, Lekakis J, Iliodromitis E, Dimitriadis G, Ikonomidis I (2018) Effects of 6-month treatment with the glucagon like peptide-1 analogue liraglutide on arterial stiffness, left ventricular myocardial deformation and oxidative stress in subjects with newly diagnosed type 2 diabetes. Cardiovasc Diabetol 17(1):1-12. https://doi.org/ 10.1186/S12933-017-0646-Z

77. Chen X, Zhang W, Tian Y, Wang L, Chen C, Qiu C (2018) Liraglutide suppresses non-esterified free fatty acids and soluble vascular cell adhesion molecule-1 compared with metformin in patients with recent-onset type 2 diabetes. Cardiovasc Diabetol 17(1):1-8. https://doi.org/10.1186/S12933-018-0701-4

78. Milani L, Galindo CM, Turin de Oliveira NM, Corso CR, Adami ER, Stipp MC, Beltrame OC, Acco A (2019) The GLP-1 analog liraglutide attenuates acute liver injury in mice. Ann Hepatol 18(6):918-928. https://doi.org/10.1016/J.AOHEP.2019.04.011

79. Besch G, Perrotti A, Salomon du Mont L, Puyraveau M, Ben-Said X, Baltres M, Barrucand B, Flicoteaux G, Vettoretti L, Samain E, Chocron S, Pili-Floury S (2018) Impact of intravenous exenatide infusion for perioperative blood glucose control on myocardial ischemia-reperfusion injuries after coronary artery bypass graft surgery: sub study of the phase II/III ExSTRESS randomized trial. Cardiovasc Diabetol 17(1):1-11. https://doi.org/10.1186/ S12933-018-0784-Y

80. Fei Y, Tsoi M-F, Cheung BMY (2019) Cardiovascular outcomes in trials of new antidiabetic drug classes: a network meta-analysis. Cardiovasc Diabetol 18(1):1-13. https://doi.org/10.1186/ S12933-019-0916-Z 
81. Seferović PM, Fragasso G, Petrie M, Mullens W, Ferrari R, Thum T, Bauersachs J, Anker SD, Ray R, Çavuşoğlu Y, Polovina M, Metra M, Ambrosio G, Prasad K, Seferović J, Jhund PS, Dattilo G, Celutkiene J, Piepoli M, Moura B, Chioncel O, Ben Gal T, Heymans S, de Boer RA, Jaarsma T, Hill L, Lopatin Y, Lyon AR, Ponikowski P, Lainščak M, Jankowska E, Mueller C, Cosentino F, Lund L, Filippatos GS, Ruschitzka F, Coats AJS, Rosano GMC (2020) Sodium-glucose co-transporter 2 inhibitors in heart failure: beyond glycaemic control. A position paper of the Heart Failure Association of the European Society of Cardiology. Eur J Heart Fail 22(9):1495-1503. https://doi.org/10.1002/EJHF.1954

82. Ni L, Yuan C, Chen G, Zhang C, Wu X (2020) SGLT2i: beyond the glucose-lowering effect. Cardiovasc Diabetol 19(1):1-10. https://doi.org/10.1186/S12933-020-01071-Y

83. Hallow KM, Helmlinger G, Greasley PJ, McMurray JJV, Boulton DW (2018) Why do SGLT2 inhibitors reduce heart failure hospitalization? A differential volume regulation hypothesis. Diabetes, Obes Metab 20(3):479-487. https://doi.org/10.1111/DOM.13126

84. Yaribeygi H, Lhaf F, Sathyapalan T, Sahebkar A (2019) Effects of novel antidiabetes agents on apoptotic processes in diabetes and malignancy: implications for lowering tissue damage. Life Sci 231:116538. https://doi.org/10.1016/J.LFS.2019.06.013

85. Sun HY, Wang NP, Halkos ME, Kerendi F, Kin H, Wang RX, Guyton RA, Zhao ZQ (2004) Involvement of $\mathrm{Na}+\mathrm{H}+$ exchanger in hypoxia/re-oxygenation-induced neonatal rat cardiomyocyte apoptosis. Eur J Pharmacol 486(2):121-131. https://doi.org/10. 1016/J.EJPHAR.2003.12.016

86. Cingolani HE, Rebolledo OR, Portiansky EL, Pérez NG, Camilión de Hurtado MC (2003) Regression of hypertensive myocardial fibrosis by $\mathrm{Na}(+) / \mathrm{H}(+)$ exchange inhibition. Hypertens 41(2):373377. https://doi.org/10.1161/01.HYP.0000051502.93374.1C

87. Young M, Funder J (2003) Mineralocorticoid action and sodiumhydrogen exchange: studies in experimental cardiac fibrosis. Endocrinology 144(9):3848-3851. https://doi.org/10.1210/EN. 2003-0039

88. Patel VB, Shah S, Verma S, Oudit GY (2017) Epicardial adipose tissue as a metabolic transducer: role in heart failure and coronary artery disease. Heart Fail Rev 22(6):889-902. https://doi.org/10. 1007/S10741-017-9644-1

89. Hussein AM, Eid EA, Taha M, Elshazli RM, Bedir RF, Lashin LS (2020) Comparative Study of the Effects of GLP1 Analog and SGLT2 inhibitor against diabetic cardiomyopathy in type 2 diabetic rats: possible underlying mechanisms. Biomedicines 8(3). https://doi.org/10.3390/BIOMEDICINES8030043

90. Yang Y, Zhao C, Ye Y, Yu M, Qu X (2020) Prospect of sodiumglucose co-transporter 2 inhibitors combined with insulin for the treatment of type 2 diabetes. Front Endocrinol 11.https://doi.org/ 10.3389/FENDO.2020.00190/FULL

91. Kario K, Ferdinand KC, O'Keefe JH (2020) Control of 24-hour blood pressure with SGLT2 inhibitors to prevent cardiovascular disease. Prog Cardiovasc Dis 63(3):249-262. https://doi.org/10. 1016/J.PCAD.2020.04.003

Publisher's Note Springer Nature remains neutral with regard to jurisdictional claims in published maps and institutional affiliations. 